\title{
Sulfate geoengineering impact on methane transport and lifetime: results from the Geoengineering Model Intercomparison Project (GeoMIP)
}

\author{
Daniele Visioni ${ }^{1,2}$, Giovanni Pitari ${ }^{1}$, Valentina Aquila ${ }^{3}$, Simone Tilmes $^{4}$, Irene Cionni ${ }^{5}$, Glauco Di Genova ${ }^{2}$, and \\ Eva Mancini ${ }^{1,2}$ \\ ${ }^{1}$ Department of Physical and Chemical Sciences, Università dell'Aquila, 67100 L'Aquila, Italy \\ ${ }^{2}$ CETEMPS, Università dell'Aquila, 67100 L'Aquila, Italy \\ ${ }^{3}$ GESTAR/Johns Hopkins University, Department of Earth and Planetary Science, 3400 N Charles Street, Baltimore, \\ MD 21218, USA \\ ${ }^{4}$ National Center for Atmospheric Research, Boulder, CO 80305, USA \\ ${ }^{5}$ ENEA, Ente per le Nuove Tecnologie, l'Energia e l'Ambiente, 00123 Rome, Italy
}

Correspondence to: Daniele Visioni (daniele.visioni@aquila.infn.it)

Received: 5 July 2017 - Discussion started: 11 July 2017

Revised: 7 September 2017 - Accepted: 11 September 2017 - Published: 21 September 2017

\begin{abstract}
Sulfate geoengineering (SG), made by sustained injection of $\mathrm{SO}_{2}$ in the tropical lower stratosphere, may impact the $\mathrm{CH}_{4}$ abundance through several photochemical mechanisms affecting tropospheric $\mathrm{OH}$ and hence the methane lifetime. (a) The reflection of incoming solar radiation increases the planetary albedo and cools the surface, with a tropospheric $\mathrm{H}_{2} \mathrm{O}$ decrease. (b) The tropospheric UV budget is upset by the additional aerosol scattering and stratospheric ozone changes: the net effect is meridionally not uniform, with a net decrease in the tropics, thus producing less tropospheric $\mathrm{O}\left({ }^{1} \mathrm{D}\right)$. (c) The extratropical downwelling motion from the lower stratosphere tends to increase the sulfate aerosol surface area density available for heterogeneous chemical reactions in the mid-to-upper troposphere, thus reducing the amount of $\mathrm{NO}_{x}$ and $\mathrm{O}_{3}$ production. (d) The tropical lower stratosphere is warmed by solar and planetary radiation absorption by the aerosols. The heating rate perturbation is highly latitude dependent, producing a stronger meridional component of the Brewer-Dobson circulation. The net effect on tropospheric $\mathrm{OH}$ due to the enhanced stratosphere-troposphere exchange may be positive or negative depending on the net result of different superimposed species perturbations $\left(\mathrm{CH}_{4}, \mathrm{NO}_{y}, \mathrm{O}_{3}, \mathrm{SO}_{4}\right)$ in the extratropical upper troposphere and lower stratosphere (UTLS). In addition, the atmospheric stabilization resulting from the tropospheric cooling and lower stratospheric warming favors an
\end{abstract}

additional decrease of the UTLS extratropical $\mathrm{CH}_{4}$ by lowering the horizontal eddy mixing. Two climate-chemistry coupled models are used to explore the above radiative, chemical and dynamical mechanisms affecting $\mathrm{CH}_{4}$ transport and lifetime (ULAQ-CCM and GEOSCCM). The $\mathrm{CH}_{4}$ lifetime may become significantly longer (by approximately $16 \%$ ) with a sustained injection of $8 \mathrm{Tg}_{-} \mathrm{SO}_{2} \mathrm{yr}^{-1}$ starting in the year 2020, which implies an increase of tropospheric $\mathrm{CH}_{4}$ $(200 \mathrm{ppbv})$ and a positive indirect radiative forcing of sulfate geoengineering due to $\mathrm{CH}_{4}$ changes $\left(+0.10 \mathrm{~W} \mathrm{~m}^{-2}\right.$ in the 2040-2049 decade and $+0.15 \mathrm{~W} \mathrm{~m}^{-2}$ in the 2060-2069 decade).

\section{Introduction}

Many geoengineering methods have been proposed in order to temporarily balance out the direct effect of the increase of anthropogenic greenhouse gas emissions (Kravitz et al., 2011). Amongst those, stemming from the observations of the effects of large volcanic eruptions, is the injection of sulfate aerosol precursors (e.g., $\mathrm{SO}_{2}$ ) into the stratosphere (Crutzen, 2006; Robock et al., 2011; Kravitz et al., 2012). The injection above the tropopause of very large amounts of particles and sulfur gases due to explosive volcanic eruptions 
is able to increase the stratospheric aerosol optical depth by more than 1 order of magnitude. The initial volcanic $\mathrm{SO}_{2}$ plume quickly nucleates into $\mathrm{H}_{2} \mathrm{SO}_{4}$ vapor (Bluth et al., 1992), producing an optically thick cloud of sulfate aerosols (McCormick and Veiga, 1992; Lambert et al., 1993; Long and Stowe, 1994). The high reflectivity of these aerosols effectively decreases the amount of solar radiation reaching the Earth's surface, thus producing a net global cooling. In 1991, for example, the Pinatubo eruption produced a reduction of the global surface air temperature from $0.5 \mathrm{~K}$ (Soden et al., 2002) to $0.14 \mathrm{~K}$ using detrended analyses (Canty et al., 2013).

Besides the direct effect on surface temperatures, however, there is the need for a thorough examination of other effects on atmospheric circulation and chemical composition of the troposphere and stratosphere brought about by the increase in lower stratosphere optical thickness (Visioni et al., 2017). The interaction of the $\mathrm{H}_{2} \mathrm{SO}_{4}$ particles with solar radiation is twofold: the aerosols increase the amount of radiation that is reflected and scattered but they also absorb part of it in the near-infrared wavelengths, increasing the lower stratospheric diabatic heating rates. This causes a local positive temperature change (Labitzke and McCormick, 1992) which induces a significant increase of westerly winds from the thermal wind equation with peaks at midlatitudes in the midstratosphere (Pitari et al., 2016c). These dynamical changes tend to increase the amplitude of planetary waves in the stratosphere and to enhance the tropical upwelling in the rising branch of the Brewer-Dobson circulation (Pitari et al., 2014; Aquila et al., 2014). For continuity, a stronger downward component is found in the lower branch of the Brewer-Dobson circulation (Aquila et al., 2013; Pitari et al., 2016b).

These dynamical changes can bring about modification in the concentration and growth rate of long-lived species that act as greenhouse gases, such as $\mathrm{N}_{2} \mathrm{O}$ and $\mathrm{CH}_{4}$, as observed in the case of the Pinatubo eruption (Schauffler and Daniel, 1994; Dlugokencky et al., 1994). An increase in the downward mid- and high-latitude fluxes in the lower stratosphere ends up advecting more stratospheric air below the tropopause, thus decreasing the tropospheric concentration of these gases. In addition, the horizontal eddy mixing in the upper troposphere and lower stratosphere (UTLS) is lowered as a consequence of the atmospheric stabilization resulting from the tropospheric cooling and lower stratospheric warming, thus decreasing the isentropic transport of $\mathrm{CH}_{4}$ and $\mathrm{N}_{2} \mathrm{O}$ from the tropical pipe towards the midlatitudes. This favors an additional decrease of the UTLS extratropical downward fluxes of $\mathrm{CH}_{4}$ and other long-lived species (Pitari et al., 2016b). The overall effect on tropospheric $\mathrm{OH}$ due this enhanced stratosphere-troposphere exchange and perturbed UTLS horizontal mixing may be positive or negative depending on the net result of different superimposed species perturbations in the UTLS $\left(\mathrm{CH}_{4}, \mathrm{NO}_{y}, \mathrm{O}_{3}\right)$.

Coupled with this perturbation of the stratospheretroposphere exchange, the lifetime of long-lived species with tropospheric $\mathrm{OH}$ sink can also be modified by other changes brought about by an injection of tropical stratospheric aerosols: (a) the surface cooling would directly lessen the amount of water vapor, thus lowering the tropospheric $\mathrm{OH}$ concentration; (b) the tropical tropospheric UV decrease due to enhanced radiation scattering would reduce the production of $\mathrm{O}\left({ }^{1} \mathrm{D}\right)$, thus decreasing $\mathrm{OH}$ production from $\mathrm{O}\left({ }^{1} \mathrm{D}\right)+\mathrm{H}_{2} \mathrm{O}$; (c) the increasing aerosol surface area density (SAD) would enhance heterogeneous chemistry in the mid-to-upper troposphere, which reduces the amount of $\mathrm{NO}_{x}$ and the rate of $\mathrm{O}_{3}$ production, both negatively affecting the amount of tropospheric $\mathrm{OH}$. Since $\mathrm{CH}_{4}$ is depleted by the $\mathrm{OH}$ radical, all these changes would mean an increase in methane lifetime (Bândǎ et al., 2013, 2015). The aim of this study is to evaluate the chemical, radiative and dynamical effects of a sustained injection of $\mathrm{SO}_{2}$ in the stratosphere on the lifetime and abundance of $\mathrm{CH}_{4}$.

The paper is organized in seven subsequent parts. Section 2 includes a description of participating models. In Sect. 3, a model evaluation for long-lived species stratospheric abundance and transport is presented using available satellite observations. Section 4 analyzes the sulfate geoengineering (SG) induced perturbations on stratospheric species transport, while Sect. 5 discusses the effects on tropospheric chemistry and $\mathrm{CH}_{4}$ direct and indirect radiative forcing components, with the overall main conclusions discussed in Sect. 6.

\section{Model experiments}

The characteristics of the experiment follow the description of experiment G4 in the Geoengineering Model Intercomparison Project (GeoMIP) (Kravitz et al., 2011). The G4 experiment consists of a constant yearly injection of $\mathrm{SO}_{2}$ in the tropical lower stratosphere. The $\mathrm{SO}_{2}$ injection is handled by the single models in the same way they simulate the Pinatubo eruption in terms of injection height. The background anthropogenic forcing corresponds to the one from the Representative Concentration Pathway 4.5 (RCP4.5) (Taylor et al., 2012). Starting from 2020,8 (or 5) $\mathrm{Tg}-\mathrm{SO}_{2} \mathrm{yr}^{-1}$ are injected in the stratosphere with a sudden stop after 50 years. An additional 20 years of model simulations are performed (up to 2090) in order to assess the termination effects of the sulfur injection. The choice of the different amounts of injected $\mathrm{SO}_{2}$ follows two reasons: for some of the analyses, we have decided to use the same simulations used in Pitari et al. (2014) with $5 \mathrm{Tg}-\mathrm{SO}_{2} \mathrm{yr}^{-1}$. However, two experiments with varying sea surface temperatures (SSTs) have also been carried out with ULAQ-CCM to identify possible changes due to these dynamics-driving mechanisms; for this reason, an injection of $8 \mathrm{Tg}-\mathrm{SO}_{2} \mathrm{yr}^{-1}$ was performed with ULAQ-CCM in order to use the CCSM-CAM4 surface temperatures that resulted from a $8 \mathrm{Tg}_{-} \mathrm{SO}_{2} \mathrm{yr}^{-1}$ injection. The main features of the participating models are summarized in Table 1. 
Table 1. Summary of main model features. The sixth column includes the stratospheric aerosol effective radius $\left(r_{\text {eff }}\right.$ in $\left.\mu \mathrm{m}\right)$ at $20 \mathrm{~km}$ over the tropics (2040-2049). Values deduced from SAGE-II observations are $0.22 \mu \mathrm{m}(\sigma=0.02 \mu \mathrm{m})$ as an average over 1999-2000 for unperturbed background conditions and $0.57 \mu \mathrm{m}(\sigma=0.03 \mu \mathrm{m})$ as an average over July 1992-June 1993 for a volcanic perturbation (i.e., Pinatubo) comparable in magnitude to $\mathrm{G} 4$ with $5 \mathrm{Tg}-\mathrm{SO}_{2}$ injection (in terms of average stratospheric mass burden of sulfate). G4 aerosols are injected at the Equator between 16 and $25 \mathrm{~km}$ altitude (uniformly) for GEOSCCM and between 18 and $25 \mathrm{~km}$ (Gaussian distribution) for ULAQCCM. MBC indicates the mixing ratio boundary condition and FBC indicates flux boundary condition.

\begin{tabular}{|c|c|c|c|c|c|}
\hline Model & Resolution $^{\mathrm{a}}$ & Ocean/land & QBO & $\begin{array}{l}\mathrm{CH}_{4} \text { surface } \\
\text { Boundary } \\
\text { Condition }\end{array}$ & $\begin{array}{l}\text { Stratospheric } \\
\text { Aerosol source }\end{array}$ \\
\hline CCSM-CAM4 & $\begin{array}{l}1.9^{\circ} \times 2.5^{\circ}, \mathrm{L} 26 \\
\text { Top: } 3 \mathrm{hPa}\end{array}$ & Coupled & No & $\mathrm{MBC}$ & $\begin{array}{l}\text { From } \mathrm{SO}_{2} \text { oxidation }^{\mathrm{b}} \\
\mathrm{G} 4 \rightarrow 8 \mathrm{Tg}-\mathrm{SO}_{2} \\
\text { (Tilmes et al., 2016) }^{\mathrm{c}}\end{array}$ \\
\hline GEOSCCM & $\begin{array}{l}2^{\circ} \times 2.5^{\circ}, \mathrm{L} 72 \\
\text { Top: } 0.01 \mathrm{hPa}\end{array}$ & $\begin{array}{l}\text { Prescribed SSTs } \\
\text { (CESM4, G4 = RCP4.5) } \\
\text { Calculated land temperatures }\end{array}$ & Internal $^{\mathrm{d}}$ & $\mathrm{MBC}$ & $\begin{array}{l}\text { From } \mathrm{SO}_{2} \text { oxidation }^{\mathrm{b}} \\
\mathrm{G} 4 \rightarrow 5 \mathrm{Tg}-\mathrm{SO}_{2} \\
\mathrm{G} 4 \rightarrow r_{\mathrm{eff}}=0.60 \mu \mathrm{m}\end{array}$ \\
\hline ULAQ-CCM (a) & $\begin{array}{l}5^{\circ} \times 6^{\circ}, \mathrm{L} 126 \\
\text { Top: } 0.04 \mathrm{hPa}\end{array}$ & $\begin{array}{l}\text { Prescribed surface } \\
\text { Temperatures } \\
\text { (CCSM-CAM4) }\end{array}$ & Nudged & $\mathrm{MBC}$ & $\begin{array}{l}\text { From } \mathrm{SO}_{2} \text { oxidation } \\
\mathrm{G} 4 \rightarrow 8 \mathrm{Tg}-\mathrm{SO}_{2} \\
\mathrm{G} 4 \rightarrow r_{\text {eff }}=0.78 \mu \mathrm{m}\end{array}$ \\
\hline ULAQ-CCM (b) & As above & As above & As above & FBC & As above \\
\hline ULAQ-CCM (c) & As above & $\begin{array}{l}\text { Prescribed SSTs } \\
\text { (CCSM-CAM4, G4 = RCP4.5) } \\
\text { Calculated land temperatures }\end{array}$ & As above & $\mathrm{MBC}$ & $\begin{array}{l}\text { From } \mathrm{SO}_{2} \text { oxidation } \\
\mathrm{G} 4 \rightarrow 5 \mathrm{Tg}-\mathrm{SO}_{2} \\
\mathrm{G} 4 \rightarrow r_{\text {eff }}=0.61 \mu \mathrm{m}\end{array}$ \\
\hline
\end{tabular}

${ }^{a}$ Latitude by longitude horizontal resolution, number of vertical layers and model top atmospheric pressure. ${ }^{\mathrm{b}}$ Forced with background aerosols from SAGE-II data for 1999. ${ }^{\mathrm{c}}$ The model is the same as described in Tilmes et al. (2016), but in this case it was run with no interactive chemistry. ${ }^{\mathrm{d}}$ Quasi-biennial oscillation (QBO) internally generated using a gravity wave drag parameterization and resolved wave forcing. ${ }^{\mathrm{e}}$ ULAQ-CCM includes aerosol microphysics $\left(\mathrm{RCP} 4.5 r_{\mathrm{eff}}=0.19 \mu \mathrm{m}\right)$.

One of these models (CCSM-CAM4) is an atmosphereocean coupled model and it has been used (without interactive chemistry) to calculate the surface temperature evolution from 2010 to 2090 for a reference RCP4.5 case and a geoengineering G4 perturbed case with $8 \mathrm{Tg}-\mathrm{SO}_{2} \mathrm{yr}^{-1}$ injected continuously from 2020 to 2070 (Kravitz et al., 2011). One of the other two models (ULAQ-CCM) has assimilated surface temperatures calculated in the CCSM-CAM4 atmosphereocean coupled model for the reference RCP4.5 and the perturbed G4 cases (i.e., two different datasets for surface temperatures), whereas the third model (GEOSCCM) has run the G4 case with RCP4.5 SSTs assimilated from the CESM atmosphere-ocean coupled model. Both models prescribe $\mathrm{CH}_{4}$ mixing ratios at the surface (except in one numerical experiment of ULAQ-CCM where emission fluxes are used, as discussed below) and do not include changes in emission fluxes due to surface temperature modifications. A more detailed description of these numerical models can be found in Tilmes et al. (2016) and Pitari et al. (2014).

In order to properly assess the different contributions to $\mathrm{CH}_{4}$ changes discussed before, three different experiments have been carried out with the ULAQ-CCM model: experiments (a) and (b) use appropriate surface temperatures for RCP4.5 and G4 cases (as previously explained), with surface $\mathrm{CH}_{4}$ treated under mixing ratio boundary condition (MBC) and flux boundary condition (FBC) approaches for (a) and (b), respectively. Experiment (c), on the other hand, uses the same SST for both RCP4.5 and G4 cases (as in GEOSCCM), with the purpose of highlighting the impact of SST changes on the G4-RCP4.5 large-scale transport perturbations. The full list of numerical experiments completed with the three models is presented in Table 2 .

The ULAQ-CCM sensitivity cases run with the FBC approach will help in assessing the role of temperature and wind changes in the $\mathrm{CH}_{4}$ lifetime perturbation under geoengineering conditions.

\section{Model evaluation}

Both ULAQ-CCM and GEOSCCM have already been extensively reviewed in the past, both on their general features (Morgenstern et al., 2017) or for issues related to this study, such as the extratropical UTLS (Hegglin et al., 2010), or surface UV (Bais et al., 2011). The shortwave radiative transfer module of the ULAQ-CCM was carefully evaluated in the AeroCom intercomparison exercise of Randles et al. (2013).

In order to properly evaluate the models regarding the specific points of this paper, however, further evaluations have been done with different sets of observations. A list of these is available in Table $3 . \mathrm{CH}_{4}$ measurements are taken by the Halogen Occultation Experiment (HALOE), 
Table 2. Summary of numerical experiments with ensemble size. The amount of injected $\mathrm{SO}_{2}$ (per year) is specified between brackets in the G4 column.

\begin{tabular}{llll}
\hline Model & RCP4.5 & G4 & Used for \\
\hline CCSM-CAM4 & 2 & $2\left(8 \mathrm{Tg}-\mathrm{SO}_{2}\right)$ & SSTs for the ULAQ-CCM simulation \\
GEOSCCM & 3 & $3\left(5 \mathrm{Tg}-\mathrm{SO}_{2}\right)$ & Assessing $\mathrm{CH}_{4}$ changes due to transport \\
ULAQ-CCM (a) & 2 & $2\left(8 \mathrm{Tg}-\mathrm{SO}_{2}\right)$ & Assessing $\mathrm{CH}_{4}$ changes due to transport \\
ULAQ-CCM (b) & 2 & $2+1^{\mathrm{a}}+1^{\mathrm{b}}+1^{\mathrm{c}}\left(8 \mathrm{Tg}-\mathrm{SO}_{2}\right)$ & Assessing $\mathrm{CH}_{4}$ changes due to chemistry \\
ULAQ-CCM (c) & 2 & $2\left(5 \mathrm{Tg}-\mathrm{SO}_{2}\right)+1^{\mathrm{d}}\left(8 \mathrm{Tg}-\mathrm{SO}_{2}\right)$ & Assessing $\mathrm{CH}_{4}$ changes due to transport and chemistry \\
\hline
\end{tabular}

${ }^{a}$ FBC sensitivity case ( $\mathrm{sn} 1$ ) with temperature and winds from RCP4.5 in the chemistry module and continuity equations of chemical tracers. ${ }^{\mathrm{b}} \mathrm{FBC}$ sensitivity case (sn2) with temperature from RCP4.5 in the chemistry module. ${ }^{\mathrm{c}} \mathrm{FBC}$ sensitivity case (sn3) with winds from RCP4.5 in the continuity equations of chemical tracers. ${ }^{\mathrm{d}}$ MBC sensitivity case for experiment (c) using the same sulfur injection as in experiments (a) and (b).

Table 3. Summary of $\mathrm{CH}_{4}$ and $\mathrm{N}_{2} \mathrm{O}$ satellite observations used in this study.

\begin{tabular}{lrr}
\hline Observation & $\mathrm{CH}_{4}$ & $\mathrm{~N}_{2} \mathrm{O}$ \\
\hline TES & $2004-2010$ & $2004-2010$ \\
HALOE & $1991-2005$ & \\
SMR & & $2001-2005$ \\
\hline
\end{tabular}

which is onboard the Upper Atmosphere Research Satellite (UARS), launched in 1991 (Russell et al., 1993). Climatologies are formed for the period 1991-2005 based on extended data from Grooß and Russell III (2005). HALOE measurements range from 15 to $60-130 \mathrm{~km}$ altitude (depending on the species) and cover $80^{\circ} \mathrm{S}$ to $80^{\circ} \mathrm{N}$ in latitude within 1 year. In all intercomparisons, the HALOE climatological mean and the interannual standard deviation $(1 \sigma)$ are shown. $\mathrm{CH}_{4}$ and $\mathrm{N}_{2} \mathrm{O}$ profiles are estimated by Aura Tropospheric Emission Spectrometer (TES) thermal infrared radiances at $\lambda=8 \mu \mathrm{m}$ with the version 5 retrieval algorithm, where $\mathrm{CH}_{4}$ is corrected using co-retrieved $\mathrm{N}_{2} \mathrm{O}$ estimates (Worden et al., 2012). Climatological mean and interannual standard deviations for both species are calculated for the period 20042010. Climatological mean and interannual standard deviation of $\mathrm{N}_{2} \mathrm{O}$ between 2001-2005 are based on the Odin/SMR product (Urban et al., 2009). A further discussion regarding TES and HALOE differences can be found in Pitari et al. (2016a), together with a more in-depth evaluation of ULAQ$\mathrm{CCM} \mathrm{CH}_{4}$ predictions.

$\mathrm{CH}_{4}$ diagnostics largely reflect the skill of the transport representation in the models. We examined climatological zonal profiles at selected latitudes, months and pressure levels for both model outputs and observations (Fig. 1). The climatologies refer to the years 1990-2010, in order to include the range of HALOE and TES observations. Both ULAQ-CCM and GEOSCCM compare well with observations and are normally in the $\pm 1 \sigma$ deviation interval, relative to the climatological zonal mean. Some spread between models appears, more evidently in the polar regions at $100 \mathrm{hPa}$. This might be due to a combination of insufficient advective high-latitude downwelling and too-strong eddy mixing in the Southern Hemisphere during the autumn season in ULAQCCM. GEOSCCM values are generally closer to observations than those of ULAQ-CCM. Otherwise, models perform quite similarly, and overall these diagnostics do not reveal major weaknesses in the simulations.

A more in-depth evaluation of transport properties in the models can be found in the Supplement regarding the correlation between $\mathrm{CH}_{4}$ and $\mathrm{N}_{2} \mathrm{O}$ and the mean age of air. The correlation between $\mathrm{CH}_{4}$ and $\mathrm{N}_{2} \mathrm{O}$ can be used to investigate transport properties relative to model and observations (SPARC-CCMVal, 2010). Figures S1 and S2 in the Supplement show $\mathrm{CH}_{4}$ vs. $\mathrm{N}_{2} \mathrm{O}$ correlations between 100 and $1 \mathrm{hPa}$. In Table S1 in the Supplement, we present Pearson correlation coefficients relative to the different latitude bands. All these panels show a compact correlation and a good agreement with the observations; the relative Pearson coefficients in Table S1a and b are always significant. Panels regarding polar regions (Figs. S1a, d and S2a, d) present a larger spread with a slightly lower (but still significant) Pearson coefficient between 90 and $60^{\circ} \mathrm{S}$. In the lower stratosphere at tropical and midlatitudes, there is a strong compact relationship between $\mathrm{CH}_{4}$ and $\mathrm{N}_{2} \mathrm{O}$ related to the slope equilibrium (Sankey and Shepherd, 2003): the mixing happens on a faster timescale than the chemical loss and transport to the surface. At polar latitudes, the correlation is affected by vortex edge, which represents a mixing barrier during the winter-spring season (Fig. S3).

Another important diagnostic for the evaluation of the model transport is based on the mean age of air (AoA). In particular, the latitudinal gradient between tropics and midlatitudes can be used to assess tropical ascent independently of quasi-horizontal mixing (SPARC-CCMVal, 2010). Following Strahan et al. (2011), tropical mean AoA profiles combine the effect of ascent rate and horizontal mixing. The agreement of model and observations only shows that the combined effects of ascent and mixing produce a realistic mean AoA in the models. Figure S3c identifies how ascent contributes to the overall tropical transport.

The horizontal gradient of mean age is able to reveal some characteristics of the Brewer-Dobson circulation (BDC) 
(a) $\mathrm{CH}_{4} 60^{\circ} \mathrm{S}$ Oct

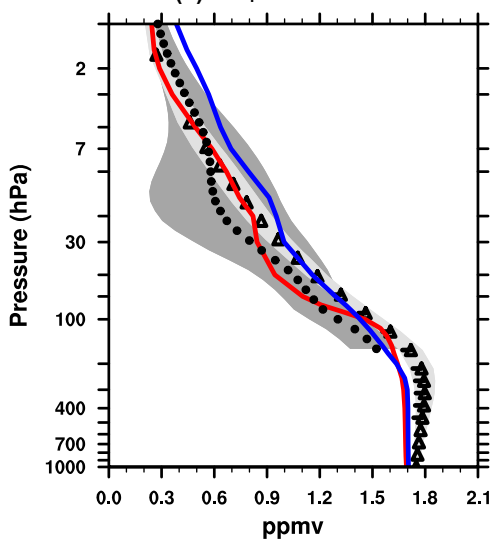

(d) $\mathrm{CH}_{4} 100 \mathrm{hPa}$ Oct

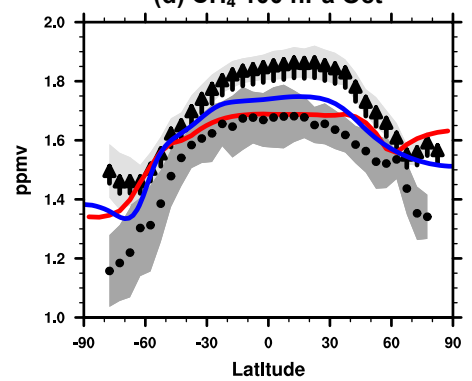

(b) $\mathrm{CH}_{4}$ Equator Jul

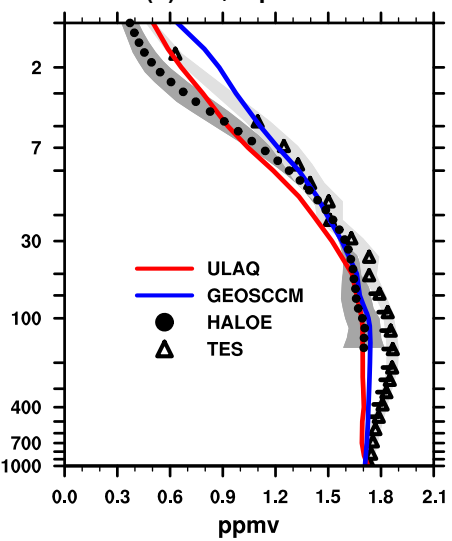

(e) $\mathrm{CH}_{4} 100 \mathrm{hPa}$ Jul

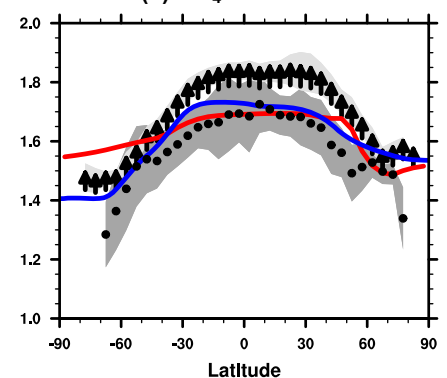

(c) $\mathrm{CH}_{4} 60^{\circ} \mathrm{N}$ Mar

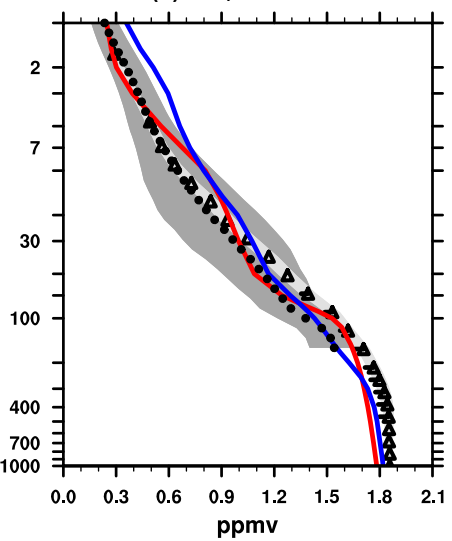

(f) $\mathrm{CH}_{4} 100 \mathrm{hPa} \mathrm{Mar}$

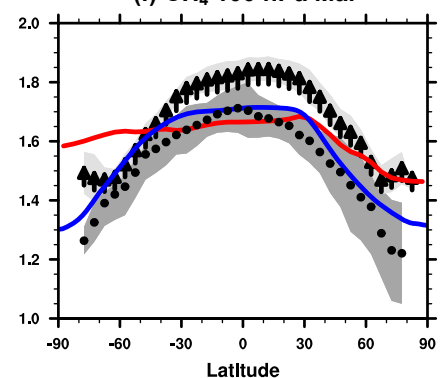

Figure 1. Evaluation of zonal and annual mean $\mathrm{CH}_{4}$ mixing ratios ULAQ-CCM (red) and GEOSCCM (blue) simulations averaged over 1991-2010. Observations are taken from HALOE (black dots, average 1991-2005) (Grooß and Russell III, 2005) and TES Aura (black triangles, average 2004-2010).

(Neu and Plumb, 1999), namely the ascent rate. In fact, differences between midlatitude and tropical values exclude horizontal mixing, since that equally affects both the tropics and midlatitudes. In GEOSCCM and ULAQ-CCM, the horizontal gradient is smaller than observations by up to $21 \mathrm{~km}$, indicating a fast ascent, but still included in the range of observed variability. The analysis of the relationship between mean AoA and $\mathrm{N}_{2} \mathrm{O}$ (Fig. S3d) evaluates the lower stratospheric transport and our use of the well-measured $\mathrm{N}_{2} \mathrm{O}$ in Figs. S1 and S2. The model values of mean AoA and $\mathrm{N}_{2} \mathrm{O}$ shown represent the climatological mean (1980-2005) in the range $10-100 \mathrm{hPa}$ and $10^{\circ} \mathrm{S}-10^{\circ} \mathrm{N}$, while observed values of mean age of air are the same as in Fig. S3a and observed values of $\mathrm{N}_{2} \mathrm{O}$ are the SMR/Odin climatological mean (20012005). The correlation for $\mathrm{N}_{2} \mathrm{O}>150 \mathrm{ppbv}$ looks compact, ad the slope of the model curves is similar to the observed curve; model values of $\mathrm{N}_{2} \mathrm{O}$ and mean AoA are in the same range as the observations. Figure $\mathrm{S} 3$ e presents the evaluation of latitudinal sections of $\mathrm{N}_{2} \mathrm{O}$ at $50 \mathrm{hPa}$ against SMR/Odin data. For tropical values, GEOSCCM and ULAQ-CCM agree very well with the observations; overall model values fall inside the $2 \sigma$ interannual variability. At northern midlatitudes, ULAQ-CCM overestimates SMR; in the Southern Hemisphere, GEOSCCM values are larger than SMR and ULAQCCM values lower.
In order to properly asses the temperature of the polar stratosphere and its interannual variability, the models must correctly simulate the vertical propagation of planetary waves from the troposphere to the stratosphere. Since it is possible to use the correlation between winter polar temperatures and eddy heat fluxes in the lower stratosphere as a proxy for planetary wave propagation, we looked at the correlation between the meridional heat flux at $100 \mathrm{hPa}\left(40\right.$ to $80^{\circ}$ for the two hemispheres) and the $50 \mathrm{hPa}$ polar temperatures (60 to $90^{\circ}$ for the two hemispheres), following Eyring et al. (2006). Table S2 in the Supplement compares the coefficients of the linear fit between the two quantities for ULAQ-CCM, GEOSCCM and the ERA40 reanalysis. The positive slope is found in both models and reanalysis, with a greater similarity in the Northern Hemisphere with respect to the Southern Hemisphere; this difference was already shown in Eyring et al. (2006).

In Fig. 2, the vertical mass fluxes are evaluated by looking at the $\mathrm{CH}_{4}$ and $\mathrm{N}_{2} \mathrm{O}$ measurements combined with the vertical velocities measured by MERRA, defining the flux as $\left[\rho w^{*}\right]$. A good agreement between measurements and models is found in the 5 to $100 \mathrm{hPa}$ profile, with GEOSCCM underestimating the vertical flux between 50 and $30 \mathrm{hPa}$. Figure S4 in the Supplement shows a latitudinal section of the 

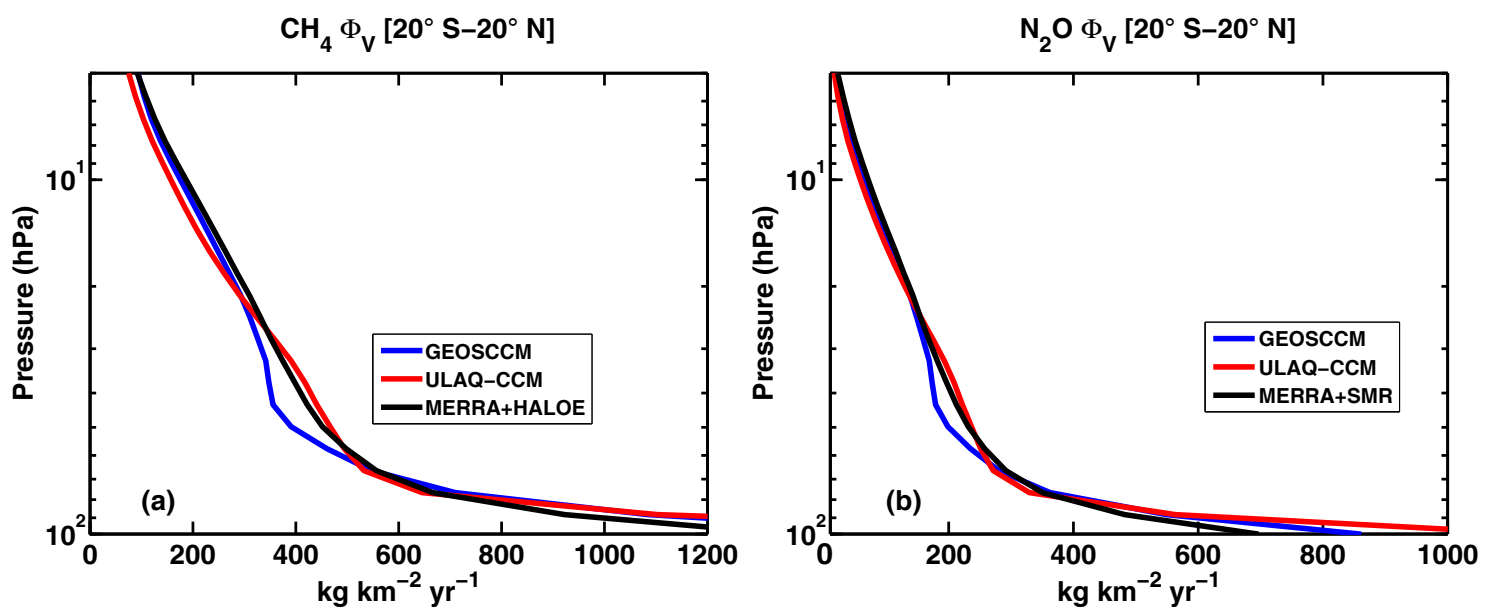

Figure 2. Tropical stratospheric vertical mass fluxes $\left(20^{\circ} \mathrm{S}-20^{\circ} \mathrm{N}\right)$ of (a) $\mathrm{CH}_{4}$ and (b) $\mathrm{N}_{2} \mathrm{O}$ for GEOSCCM (blue) and ULAQ-CCM (red) results; the vertical mass fluxes are defined as $\left[\rho w^{*}\right]$, where $w^{*}$ is the zonal mean residual vertical velocity and $\rho$ is the zonally averaged mass concentration of $\mathrm{CH}_{4}$ and $\mathrm{N}_{2} \mathrm{O}$, respectively. A model evaluation is made with flux data obtained with $w^{*}$ from MERRA reanalysis and $\mathrm{CH}_{4}, \mathrm{~N}_{2} \mathrm{O}$ mixing ratios from HALOE and SMR results (black) $\left(\mathrm{kg} \mathrm{km}^{-2} \mathrm{yr}^{-1}\right) . \mathrm{CH}_{4}$ and $\mathrm{N}_{2} \mathrm{O}$ fluxes are averaged over 1991-2005 and 2001-2005, respectively, to keep consistency with the adopted HALOE and SMR mixing ratio values.

heat fluxes in order to further evaluate the transport skill of the two models.

\section{Perturbation of stratospheric species transport}

Absorption of solar near-infrared (NIR) and planetary radiation by the geoengineering aerosols produces an increase of diabatic heating rates in the tropical lower stratosphere, resulting in local warming, changes in the latitudinal distribution of zonal winds, changes of the equatorial quasi-biennial oscillation (QBO) (Aquila et al., 2014) and a strengthening of the stratospheric Brewer-Dobson circulation (BDC) (Pitari et al., 2014). Enhanced tropical upwelling (about 5-10\% increase in vertical velocities in the lower stratosphere) and extratropical descent tend to move $\mathrm{CH}_{4}$ poor air more efficiently towards the extratropical UTLS, as well as for other stratospheric long-lived species. The net impact on tropospheric $\mathrm{OH}$ and $\mathrm{CH}_{4}$ lifetime depends on the net result of superimposed species perturbations in the UTLS $\left(\mathrm{CH}_{4}, \mathrm{NO}_{y}\right.$, $\mathrm{O}_{3}, \mathrm{SO}_{4}$ ), in addition to tropospheric chemistry perturbations due to changes in water vapor content, UV radiation and heterogeneous reactions on sulfate aerosols that affect the $\mathrm{NO}_{x}$ balance.

The 5-10\% increase of stratospheric tropical upward mass fluxes of both $\mathrm{CH}_{4}$ and $\mathrm{N}_{2} \mathrm{O}$, as shown in Fig. 3a, b, is predicted by the models in geoengineering conditions as a consequence of the increasing tropical midstratospheric upwelling, with a larger anomaly in GEOSCCM with respect to both MBC experiments run with the ULAQ-CCM (cases a and $\mathrm{c}$ in Table 1, with 8 and $5 \mathrm{Tg}-\mathrm{SO}_{2}$ injected, respectively). The choice to only include MBC experiments when discussing vertical mass flux anomalies is made in order to bet- ter highlight transport anomalies, because in the FBC experiment the anomaly would be largely masked by the increasing amount of tropospheric $\mathrm{CH}_{4}$. The larger GEOSCCM anomaly could be explained by the QBO modification produced by geoengineering aerosols, since the prolonged lower stratospheric westerly phase produces a better tropical confinement (Trepte and Hitchman, 1992; Aquila et al., 2014; Visioni et al., 2017). This effect is absent in the ULAQ-CCM model, which does not have an internally generated QBO, but specifies the QBO with observed equatorial zonal wind data using a nudging procedure (Morgenstern et al., 2010).

The UTLS horizontal mixing anomalies (Fig. 3c, d) are larger in case (a) of ULAQ-CCM with respect to ULAQCCM (c) and GEOSCCM. In the latter, two model simulations, RCP4.5 SSTs are used for both the baseline and the geoengineering perturbed experiments, whereas ULAQCCM (a) is driven in the latter experiment by G4 surface temperatures (from CCSM-CAM4). In this case, the larger decrease of the UTLS horizontal mixing can be explained by the increased atmospheric stabilization caused by the sea surface cooling, which is not present in GEOSCCM and ULAQCCM (c). The ULAQ-CCM (c) results do not change significantly in a sensitivity simulation made by increasing the stratospheric sulfur injection from 5 to $8 \mathrm{Tg}-\mathrm{SO}_{2} \mathrm{yr}^{-1}$ (see Table 2), pointing out the important role of the decreasing horizontal mixing resulting from sea surface cooling as in ULAQ-CCM (a).

The time series of model calculated $\mathrm{CH}_{4}$ and $\mathrm{N}_{2} \mathrm{O}$ changes in the UTLS is presented in Fig. 4 for ULAQ-CCM and GEOSCCM. If we compare the ULAQ-CCM case (c) with GEOSCCM, the results of the two models are similar for $\mathrm{N}_{2} \mathrm{O}$ and are consistent with changes of lower stratospheric 

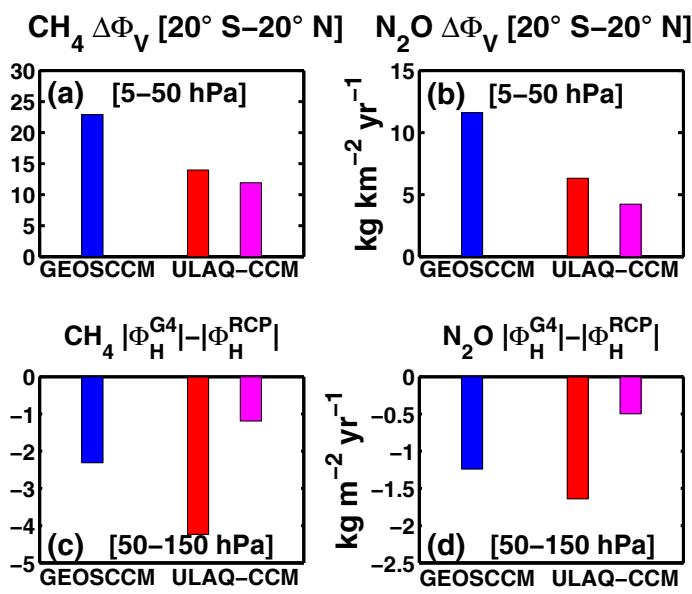

Figure 3. G4-RCP4.5 anomalies of (a, b) vertical and (c, d) horizontal mass fluxes of (a, c) $\mathrm{CH}_{4}$ and (b, d) $\mathrm{N}_{2} \mathrm{O}$ (years 2040-2049 time average). Vertical mass fluxes in panels $(\mathbf{a}, \mathbf{b})$ (defined as in Fig. 2) are averaged over the tropics $\left(20^{\circ} \mathrm{S}-20^{\circ} \mathrm{N}\right)$ in the $5-50 \mathrm{hPa}$ vertical layer, with GEOSCCM results in blue and ULAQ-CCM results in red and magenta for cases (a) and (c) as in Table 1, respectively $\left(\mathrm{kg} \mathrm{km}^{-2} \mathrm{yr}^{-1}\right)$. Horizontal mass fluxes in panels $(\mathbf{c}, \mathbf{d})$ (defined as $v \rho$, with $v$ and $\rho$ the 3-D meridional wind component and mass concentration of $\mathrm{CH}_{4}$ and $\mathrm{N}_{2} \mathrm{O}$, respectively) are averaged (in absolute values) over the extratropics (90-20 $\mathrm{S}$ and $20-90^{\circ} \mathrm{N}$ ) in the $50-150 \mathrm{hPa}$ vertical layer, with model results as in panels $(\mathbf{a}, \mathbf{b})$ $\left(\mathrm{kg} \mathrm{m}^{-2} \mathrm{yr}^{-1}\right)$.

heating rates and $\mathrm{BDC}$ (due to aerosols and $\mathrm{O}_{3}$ ). The $\mathrm{N}_{2} \mathrm{O}$ anomalies are of the order of $-1 \mathrm{ppbv}$ in both models (that is about $-0.3 \%$ ), while those of $\mathrm{CH}_{4}$ are of the order of $-5 \mathrm{ppbv}$ in the ULAQ model and about a factor of 2 smaller in GEOSCCM. This is due to missing chemical processes in the upper troposphere in GEOSCCM, where tropospheric $\mathrm{OH}$ is kept fixed at $\mathrm{RCP} 4.5$ values.

As already discussed in Fig. 3, the UTLS anomalies G4RCP4.5 are rather different for ULAQ-CCM (a), mostly as a consequence of the changing SSTs in G4, with decreased horizontal mixing in the UTLS and enhanced isolation of the tropical pipe. The negative anomaly of $\mathrm{N}_{2} \mathrm{O}$ (a quasi-passive tracer) increases up to 2-4 ppbv after 2030, whereas the negative $\mathrm{CH}_{4}$ anomaly increases up to approximately $10 \mathrm{ppbv}$ between 2030 and 2050. A clear sign inversion is predicted after 2050 for the $\mathrm{CH}_{4}$ anomaly in geoengineering conditions as a consequence of a negative $\mathrm{OH}$ trend resulting from superimposed effects of $\mathrm{NO}_{x}$ and $\mathrm{O}_{3}$. A positive trend of stratospheric $\mathrm{O}_{3}$ is, in fact, predicted in $\mathrm{G} 4$ with respect to RCP4.5 due to the lowering chlorine-bromine loading in the atmosphere in the 21st century (Pitari et al., 2014).

The zonally averaged changes of $\mathrm{N}_{2} \mathrm{O}$ and $\mathrm{CH}_{4}$ are presented in Fig. 5, with a comparison of model results from GEOSCCM and ULAQ-CCM (a). The midstratospheric changes are quite comparable between the two models, whereas the UTLS negative anomalies in ULAQ-CCM
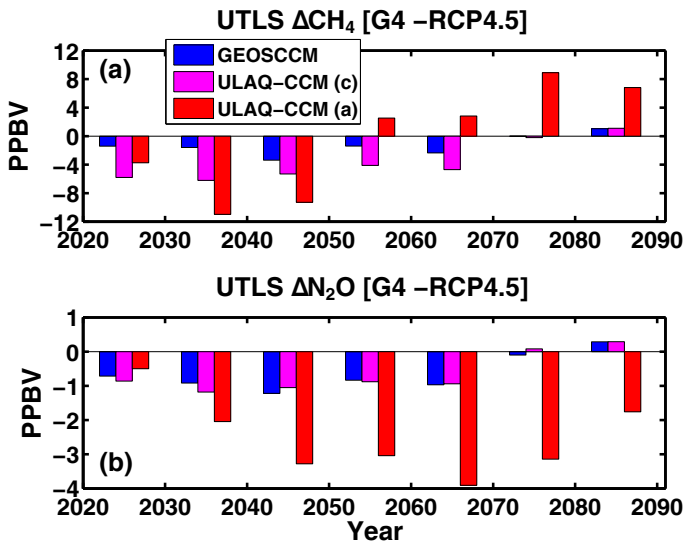

Figure 4. Time series of globally averaged changes of $\mathrm{CH}_{4}$ (a) and $\mathrm{N}_{2} \mathrm{O}$ (b) in the 50-150 hPa vertical layer for GEOSCCM (blue) and ULAQ-CCM (red and magenta, for cases (a) and (c) as in Table 1, respectively) (decadal averages). Units are ppbv.

(a) are significantly larger for the reasons discussed above in Figs. 3-4, they are fully comparable when considering GEOSCCM and ULAQ-CCM (c) results, as shown in Fig. S5. Again, this points out the sea surface cooling role on the UTLS horizontal mixing in sulfate geoengineering conditions. Further remaining differences between GEOSCCM and ULAQ-CCM (c) regarding horizontal mixing can be explained by a different treatment of QBO, which is modified in GEOSCCM with a prolonged e-shear in the G4 simulation. Interhemispheric asymmetries in the lower stratospheric mixing ratio anomalies of ULAQ-CCM (a) and their differences with respect to GEOSCCM can be explained by a combination of vertical and horizontal mass flux changes and will be addressed later on in the discussion.

To better understand the differences between the cases with fixed SSTs and the one with changing SSTs, in Fig. 6 we show the anomalies in sea surface temperatures used in ULAQ-CCM (a) and (b) against the ones used in ULAQCCM (c); surface temperatures are taken from the CCSMCAM4 atmosphere-ocean coupled model for RCP4.5 and $\mathrm{G} 4$ simulations (with an injection of $8 \mathrm{Tg}-\mathrm{SO}_{2}$ ), as described in Table 2. The zonally averaged surface temperature anomalies G4-RCP4.5 are presented in Fig. 6a for the various decades from 2020 to 2090. A strong interhemispheric asymmetry is evident, with a negative anomaly more pronounced in the Arctic region by approximately $1.5 \mathrm{~K}$ with respect to the latitude range $50-70^{\circ} \mathrm{S}$. The geoengineering cooling impact on Arctic sea ice is the main driver for the larger negative temperature anomaly in the Northern Hemisphere high latitudes, which favors a more pronounced atmospheric stabilization in the Northern Hemisphere winter-spring months with respect to the Southern Hemisphere. The time series of the globally averaged surface temperature anomalies is shown in Fig. 6b for the RCP4.5 and G4 cases: the slow oceanic response coupled to the atmospheric perturbation of 
long-lived species delays the surface temperature return in G4 to RCP4.5 values by more than one decade.

The decreased horizontal fluxes of long-lived species discussed in Fig. 3 for the ULAQ-CCM simulations with changing SSTs are a direct consequence of the atmospheric stabilization. As shown in Fig. 6c, the increased atmospheric stability in sulfate geoengineering conditions may be partially counterbalanced by the increased longitudinal variability of the induced cooling, in particular in the Northern Hemisphere, which may enhance the amplitude of planetary waves. Regions of oceanic warming in the sub-Arctic are a consequence of the increasing amount of sea ice in G4 and related enhanced transport of colder and saltier waters towards the subpolar regions (Tilmes et al., 2009). This favors cold sea water downwelling and thus positive anomalies of SSTs with respect to reference RCP4.5 conditions, mainly in the North Atlantic region (where the decrease of sea ice would produce less saltier waters, followed by less downwelling, leading to cooler SSTs).

Lastly, we show the anomalies of vertical and horizontal fluxes in Figs. 7 and 8, respectively, for ULAQ-CCM (a) and for GEOSCCM. For ULAQ-CCM (a), a $5 \%$ increase of the midstratospheric tropical upward fluxes is predicted in G4 with respect to the reference RCP4.5 case, with a pronounced interhemispheric asymmetry. The Southern Hemisphere increase of downward mass fluxes is much larger than in the Northern Hemisphere, both in absolute and relative units. The stratospheric mean meridional circulation is more efficiently perturbed in the Southern Hemisphere due to the more effective atmospheric stabilization in the Northern Hemisphere (see above; Fig. 6). A 5-10\% decrease of the extratropical horizontal mass fluxes is also predicted, as expected from the discussion above for Fig. 6. The isolation of the tropical pipe is increased in a dynamical regime with increased tropical upwelling and enhanced atmospheric stabilization. The importance of SST changes due to geoengineering is highlighted by the much smaller interhemispheric difference shown by GEOSCCM for the downward fluxes, as well as in ULAQ-CCM (c) (not shown), while the increase in the tropical upward fluxes in Fig. 7 is comparable to the ULAQ-CCM results. Furthermore, due to less atmospheric stabilization, GEOSCCM shows much smaller changes in extratropical horizontal fluxes (Fig. 8). This is further highlighted in Fig. S6, where the horizontal mass flux anomalies are also shown for ULAQ-CCM (c). In this figure, the difference between the two ULAQ-CCM simulations regarding the horizontal mass flux anomalies is clearly visible, with ULAQ-CCM (c) having latitudinal means 1 order of magnitude smaller compared to ULAQ-CCM (a) and much more comparable to GEOSCCM in the extratropics.

Another highlight of the different effects of transport and chemical effects on lifetimes is shown in Table 4, where atmospheric lifetime anomalies are shown for five species with stratospheric photolysis and $\mathrm{O}\left({ }^{1} \mathrm{D}\right)$ reaction, as calculated in ULAQ-CCM (b). The net lifetime changes G4-RCP4.5 result from the superposition of two effects: perturbation of species transport and sulfate-aerosol-induced changes in $\mathrm{O}_{3}$ via $\mathrm{NO}_{x}$ depletion from heterogeneous chemical reactions. The increased tropical upwelling moves these long-lived species more efficiently at higher altitudes in the midstratosphere where the photolysis sink is enhanced, thus decreasing the lifetimes. On the other hand, the chemically induced ozone increase (due to the $\mathrm{NO}_{x}$ sink by sulfate aerosols) tends to increase the overhead column, with a decreased midstratospheric UV flux. As a consequence, the photolysis rates decrease, thus prolonging the lifetimes. As shown in Pitari et al. (2014), however, the net effect on ozone of the aerosolinduced $\mathrm{NO}_{x}$ depletion is not constant in time due to the decreasing amount of $\mathrm{Cl}-\mathrm{Br}$ species during the 21 st century.

\section{Perturbation of tropospheric chemistry}

Stratosphere-troposphere exchange of geoengineering sulfate enhances the aerosol SAD in the upper troposphere, thus favoring $\mathrm{NO}_{x}$ depletion through heterogeneous chemical reactions (i.e., hydrolysis of $\mathrm{N}_{2} \mathrm{O}_{5}$ and $\mathrm{BrONO}_{2}$ ) (Tilmes et al., 2009). Again, this implies less $\mathrm{OH}$ production and a longer $\mathrm{CH}_{4}$ lifetime (mostly via $\mathrm{NO}+\mathrm{HO}_{2} \rightarrow \mathrm{NO}_{2}+\mathrm{OH}$ ). Figure 9 compares the G4-RCP4.5 anomalies of sulfate aerosol mass and surface area density in the UTLS, as calculated in ULAQ-CCM (c) and GEOSCCM. The ULAQ-CCM model results are taken from numerical experiments (c) in Table 1 in order to make a more meaningful comparison with GEOSCCM (same injection of $5 \mathrm{Tg}-\mathrm{SO}_{2} \mathrm{yr}^{-1}$; SSTs in G4 with respect to RCP4.5).

A combination of isentropic $\mathrm{SO}_{4}$ transport above the tropopause and tropical upwelling/extratropical descent produces aerosol accumulation in the extratropical lower stratosphere with a clear maximum of mass density in the Northern Hemisphere ( $>2 \mu \mathrm{g} \mathrm{m}^{-3}$ at $\sim 12-14 \mathrm{~km}$ altitude). Larger values in the ULAQ-CCM of both SAD and mass density in the tropical upper troposphere are due to a more efficient gravitational settling of the particles. An important difference between the two models is that ULAQ-CCM includes an aerosol microphysics code for predicting the particle size distribution, which, on the other hand, is assigned in GEOSCCM. A comparison of the simulated stratospheric distribution of the $\mathrm{SO}_{4} \mathrm{SAD}$ is shown in Fig. S7 in order to highlight the ability of both models to correctly simulate the tropical aerosol confinement, and a further discussion of the differences between the two models in this aspect, together with profile evaluation using SAGE II data, is presented in Pitari et al. (2014).

The two models predict an increase of SAD ranging between 2 and $10 \mu \mathrm{m}^{2} \mathrm{~cm}^{-3}$ in the extratropical upper troposphere, and this increase is the major diver for tropospheric $\mathrm{NO}_{x}$ changes in geoengineering conditions. Enhanced heterogeneous $\mathrm{NO}_{x}$ conversion to $\mathrm{HNO}_{3}$ on the aerosol surface ends up limiting the efficiency of reac- 

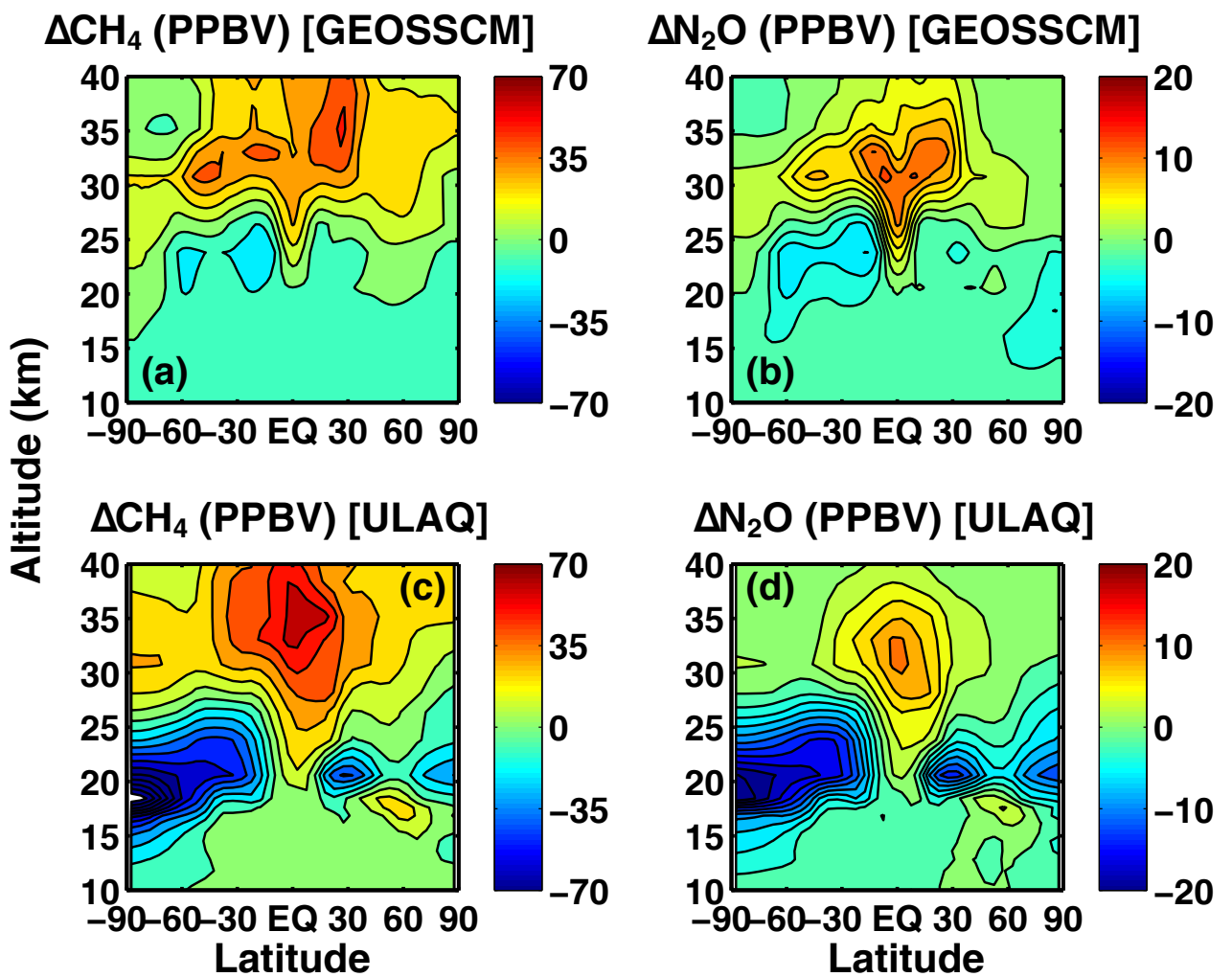

Figure 5. Zonal mean mixing ratio anomalies G4-RCP4.5 for (a, b) GEOSCCM and (c, d) ULAQ-CCM, $\mathrm{CH}_{4}(\mathbf{a}, \mathbf{c})$ and $\mathrm{N}_{2} \mathrm{O}(\mathbf{b}, \mathbf{d})$ (time average 2040-2049). ULAQ-CCM results are for case (a) in Table 1. Units are ppbv. In panels (a, c), the contour line increment is 10; in panels $(\mathbf{b}, \mathbf{d})$, the contour line increment is 2 .

Table 4. Atmospheric lifetimes (years) calculated in the ULAQ-CCM (case b in Table 1), relative to five species with stratospheric photolysis and $\mathrm{O}\left({ }^{1} \mathrm{D}\right)$ reaction sink (i.e., $\mathrm{N}_{2} \mathrm{O}$, CFC-11, H1301, CFC-12, CFC-114). The first column shows year 2000 values (as an average over the 1996-2005 decade); the second column shows a model mean from the SPARC (2013) report on lifetimes. Subsequent columns show the calculated lifetime anomalies due to sulfate geoengineering (average 2030-2069). Inside the square brackets we highlight the physical and chemical effects driving the lifetime changes: changing stratospheric transport in the fourth column and changing stratospheric $\mathrm{O}_{3}$ in the fifth column (due to the aerosol-induced $\mathrm{NO}_{x}$ loss). Results in the rightmost two columns are obtained through G4 sensitivity experiments (sn1, sn3) explained in Table 2.

\begin{tabular}{lrrrrr}
\hline 1996-2005 & $\begin{array}{r}\text { Model mean } \\
\text { (SPARC, 2013) }\end{array}$ & $\begin{array}{r}\text { 2030-2069 } \\
\text { G4-RCP4.5 } \\
\text { (all effects) }\end{array}$ & $\begin{array}{r}\text { 2030-2069 } \\
\text { G4-G4(sn3) } \\
\text { (transport) }\end{array}$ & $\begin{array}{r}\text { 2030-2069 } \\
\text { G4(sn1)-RCP4.5 } \\
\left(\text { NO }_{x} \rightarrow \mathrm{O}_{3} \rightarrow \text { UV) }\right.\end{array}$ \\
\hline $\mathrm{N}_{2} \mathrm{O}$ & 116.1 & $115.0 \pm 9.0$ & -0.4 & -3.0 & +2.6 \\
$\mathrm{CFC}-11$ & 52.2 & $55.3 \pm 4.2$ & +2.2 & -0.2 & +2.4 \\
$\mathrm{H} 1301$ & 77.9 & $73.4 \pm 4.7$ & +1.1 & -1.4 & +2.6 \\
$\mathrm{CFC}-12$ & 92.0 & $94.7 \pm 7.3$ & -0.1 & -2.7 & +2.6 \\
$\mathrm{CFC}-114$ & 202 & $189 \pm 18$ & -2.3 & -4.9 & +2.6 \\
\hline
\end{tabular}

tion $\mathrm{NO}+\mathrm{HO}_{2} \rightarrow \mathrm{NO}_{2}+\mathrm{OH}$, thus reducing $\mathrm{OH}$ and upper tropospheric $\mathrm{O}_{3}$ production, with a consequently longer $\mathrm{CH}_{4}$ lifetime. Figure 10 shows the ULAQ model calculated anomaly of UTLS $\mathrm{NO}_{x}$ in experiment (b) of Table 1, with values ranging between -0.02 and $-0.2 \mathrm{ppbv}$ in the upper troposphere (10 to $30 \%$ reduction).
The tropospheric $\mathrm{OH}$ balance is also affected also by the UV amount available for $\mathrm{O}\left({ }^{1} \mathrm{D}\right)$ production from $\mathrm{O}_{3}$ photolysis $\left(\mathrm{H}_{2} \mathrm{O}+\mathrm{O}\left({ }^{1} \mathrm{D}\right) \rightarrow 2 \mathrm{OH}\right)$ and indirectly from the upper tropospheric $\mathrm{O}_{3}$ reduction due to the decreased chemical production from $\mathrm{NO}+\mathrm{HO}_{2}$ and $\mathrm{NO}+\mathrm{RO}_{2}$. Upper tropospheric ozone, however, is also affected by perturbed stratospheretroposphere (strat-trop) fluxes and lower stratospheric ozone 


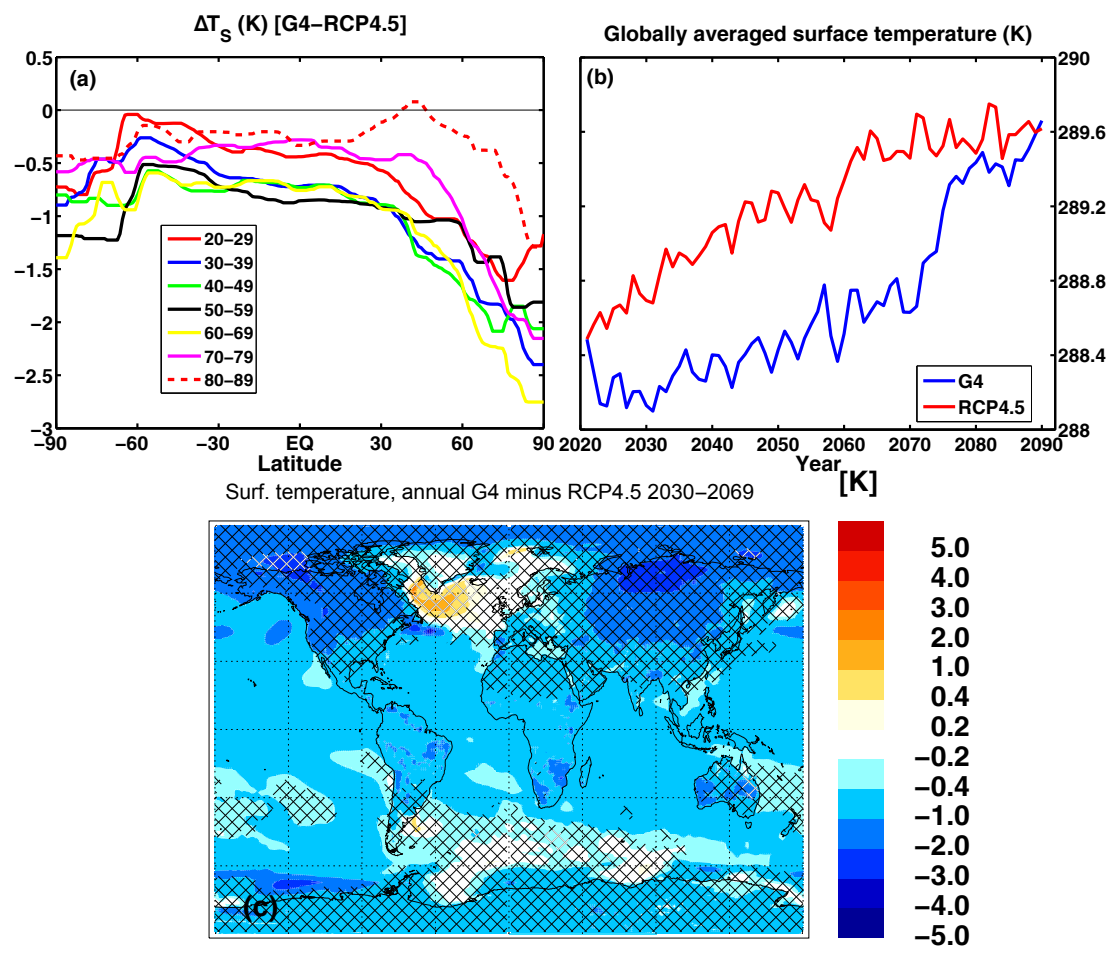

Figure 6. (a) Zonally averaged surface temperature changes G4-RCP4.5 (K) in the ULAQ-CCM (cases a and b), using sea surface temperatures from the atmosphere-ocean coupled model CCSM-CAM4 (decadal time averages from 2020 to 2089; see legend for the different colors). (b) Time series of the globally averaged surface temperatures (K) from 2020 to 2090 (RCP4.5 in red and G4 in blue). (c) Annually averaged surface temperature anomalies G4-RCP4.5 (K) from the atmosphere-ocean coupled model CCSM-CAM4 (time average 2030-2069). Shaded areas are not statistically significant within $\pm 1 \sigma$.

depletion in geoengineering conditions (Pitari et al., 2014; Xia et al., 2017). High-latitude stratospheric ozone depletion produces significant UVB increase at the surface (Tilmes et al., 2012). On the other hand, the enhanced radiation scattering in the tropical lower stratosphere overbalances the UVB increase due to tropical stratospheric ozone losses, ending up in a net decrease of tropical tropospheric UVB, which means again less $\mathrm{OH}$ production and longer $\mathrm{CH}_{4}$ lifetime (regulated essentially by tropical $\mathrm{OH}$ ). Figure 11 shows the percent anomalies of UVB as calculated in GEOSCCM and ULAQ-CCM (c) for the two components that are explicitly online in the models $\left(\mathrm{O}_{3}\right.$ and sulfate aerosols). A 1.5 to $2.0 \%$ UVB decrease is predicted by the models equatorward of $40^{\circ}$ latitude in both hemispheres $(-1.60 \%$ for GEOSCCM and $-1.94 \%$ for ULAQ-CCM). The sulfate geoengineering impact on tropospheric UV penetration and heterogeneous chemistry changes has been widely discussed in Xia et al. (2017), along with their effects on surface ozone concentration.
Solar radiation reflection by geoengineering aerosols increases the planetary albedo and cools the surface, with a tropospheric water vapor decrease as a response to this cooling: less $\mathrm{OH}$ is produced by reaction $\mathrm{H}_{2} \mathrm{O}+\mathrm{O}\left({ }^{1} \mathrm{D}\right)$, thus prolonging the $\mathrm{CH}_{4}$ lifetime. The combination of this climatechemistry effect with the others discussed above $\left(\mathrm{NO}_{x}, \mathrm{UV}\right.$, strat-trop $\mathrm{O}_{3}$ transport) produces the net $\mathrm{OH}$ perturbation in G4 with respect to RCP4.5 (Fig. 12a) and the resulting $\mathrm{CH}_{4}$ change (Fig. 12b). The calculated average tropospheric anomaly of $\mathrm{CH}_{4}$ is $+190 \mathrm{ppbv}$, i.e., $10.6 \%$ with respect to the RCP4.5 base case average mixing ratio in the years 2040 2049. The stratospheric anomalies are consistent with those discussed in Fig. 5c, obtained with the same G4 perturbation, but using the MBC approach (ULAQ-CCM a).

Any attempt to assess the long-term atmospheric response of $\mathrm{CH}_{4}$ to $\mathrm{OH}$ changes needs the surface mixing ratio to be allowed to respond freely to tropospheric perturbations of its main sink process (i.e., oxidation by $\mathrm{OH}$ ), which determines the $\mathrm{CH}_{4}$ lifetime. The usual modeling approach of adopting an assigned time-dependent mixing ratio as a surface boundary condition (MBC) can still be used to calculate climatechemistry-induced changes in $\mathrm{CH}_{4}$ lifetime, but this cannot provide information on the tropospheric mass changes of $\mathrm{CH}_{4}$ induced by the $\mathrm{OH}$ perturbations. In addition, to ob- 

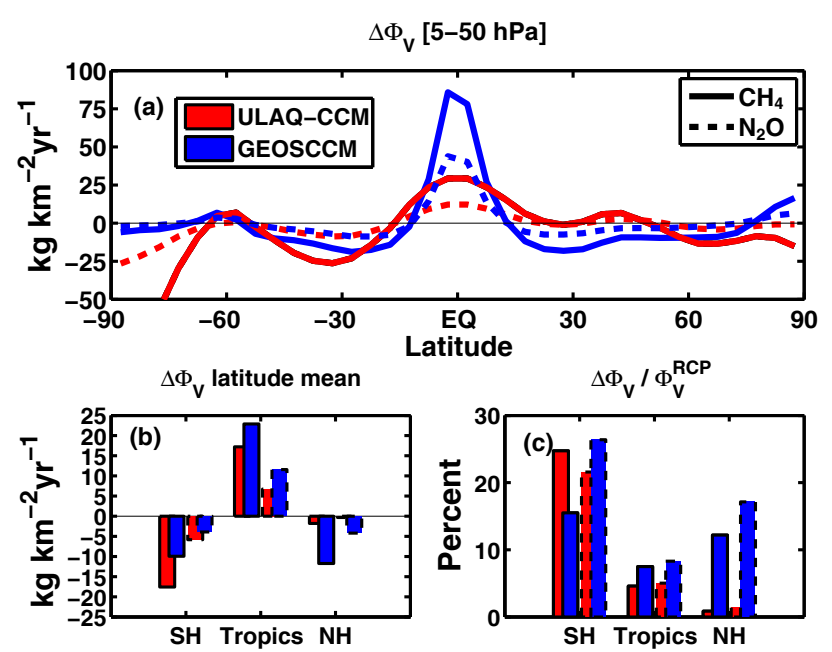

Figure 7. (a) Latitude dependent $\mathrm{CH}_{4}$ (solid line) and $\mathrm{N}_{2} \mathrm{O}$ (dashed line) vertical mass flux anomalies G4-RCP4.5 from the ULAQCCM (a) and GEOSCCM calculations, in red and blue, respectively (vertical average 5-50 hPa; time average 2040-2049). Units are $\mathrm{kg} \mathrm{km}^{-2} \mathrm{yr}^{-1}$. Panels $(\mathbf{b}, \mathbf{c})$ show the corresponding latitude averaged mass flux anomalies (absolute and percent values, respectively): $\mathrm{SH}$ from 90 to $20^{\circ} \mathrm{S}$; tropics from $20^{\circ} \mathrm{S}$ to $20^{\circ} \mathrm{N}$; $\mathrm{NH}$ from 20 to $90^{\circ} \mathrm{N}$. The vertical flux anomalies $\Delta \Phi_{\mathrm{V}}$ are defined as $\Delta\left[w^{*} \rho_{\mathrm{CH}_{4}}\right]$ and $\Delta\left[w^{*} \rho_{\mathrm{N}_{2} \mathrm{O}}\right]$, where $w^{*}$ is the zonal mean residual vertical velocity, $\rho_{\mathrm{CH}_{4}}$ and $\rho_{\mathrm{N}_{2} \mathrm{O}}$ are the mass concentrations of $\mathrm{CH}_{4}$ and $\mathrm{N}_{2} \mathrm{O}$, respectively, and $\Delta$ denotes the G4-RCP4.5 difference.

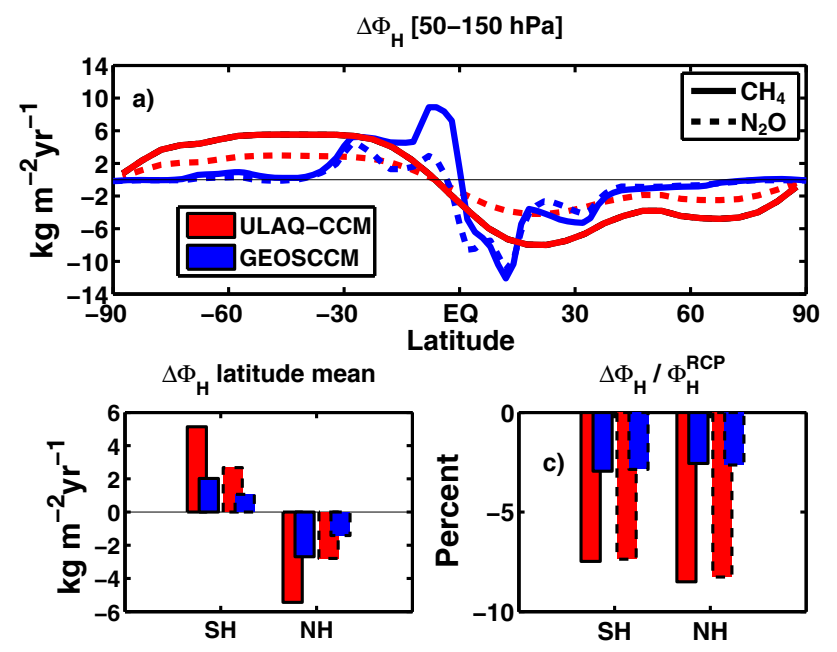

Figure 8. As in Fig. 7 but for horizontal mass flux anomalies G4RCP4.5 (vertical average 50-150 hPa; time average 2040-2049). Units are $\mathrm{kg} \mathrm{m}^{-2} \mathrm{yr}^{-1}$. The horizontal flux anomalies $\Delta \Phi_{\mathrm{H}}$ are defined as $\Delta\left[v \rho_{\mathrm{CH}_{4}}\right]$ and $\Delta\left[v \rho_{\mathrm{N}_{2} \mathrm{O}}\right]$, where $v$ is the 3-D meridional wind component.

tain a correct estimate of the lifetime perturbation, the MBC approach would necessitate the use of correction factors, due

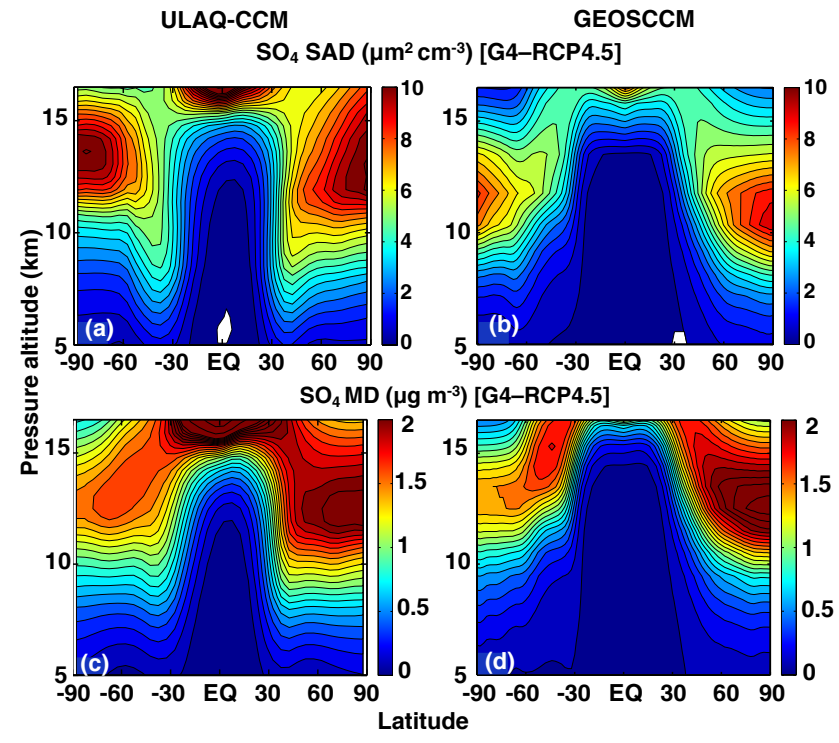

Figure 9. G4-RCP4.5 anomalies of sulfate aerosol surface area density $(\mathbf{a}, \mathbf{b})$ and mass density $(\mathbf{c}, \mathbf{d})$ in the upper troposphere and lowermost stratosphere from ULAQ-CCM $(\mathbf{a}, \mathbf{c})$ and GEOSCCM $(\mathbf{b}, \mathbf{d})$ (time average 2040-2049). ULAQ-CCM results are from numerical experiments (c) in Table 1. Units are $\mu \mathrm{m}^{2} \mathrm{~cm}^{-3}$ for the surface area and $\mu \mathrm{g} \mathrm{m}^{-3}$ for the mass density. In panels $(\mathbf{a}, \mathbf{b})$, the contour line increment is 0.5 for values less than 12 and 2.0 from 14 to larger values. In panels $(\mathbf{c}, \mathbf{d})$, the contour line increment is 0.1 for values less than 2.5 and 1.0 from 3.0 to larger values.

(a) $\Delta \mathrm{NO}_{x}$ (ppbv) $[\mathrm{G} 4(\mathrm{FBC})-\mathrm{RCP} 4.5]$

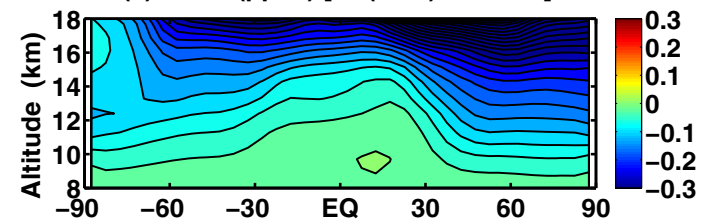

(b) $\Delta \mathrm{NO}_{x}$ (percent)

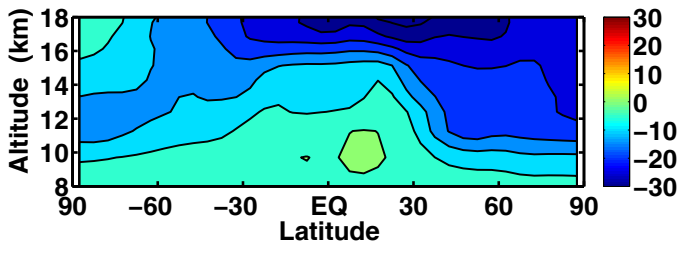

Figure 10. G4-RCP4.5 anomalies of $\mathrm{NO}+\mathrm{NO}_{2}$ mixing ratios in the upper troposphere and lowermost stratosphere from experiment (b) of the ULAQ-CCM (time average 2040-2049). Panels (a, b) are for absolute (ppbv) and percent $\mathrm{NO}_{x}$ changes, respectively. The contour line increments are $0.025 \mathrm{ppbv}$ and $5 \%$ in panels (a, b), respectively.

to the missing feedback of lower tropospheric $\mathrm{CH}_{4}$ changes on $\mathrm{HO}_{x}$ chemistry (Myhre et al., 2011).

The alternative approach of using a surface flux boundary condition (FBC) would, in principle, resolve these issues. Table 5 summarizes $\mathrm{CH}_{4}$ surface emissions, sinks, global mass 


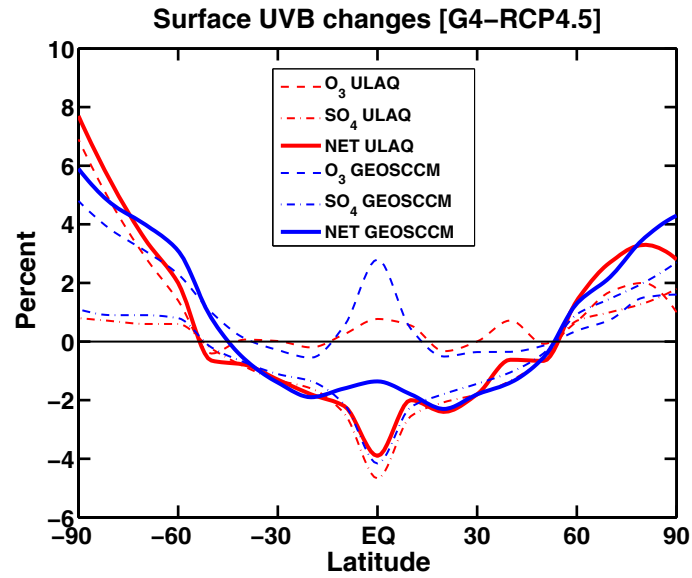

Figure 11. G4-RCP4.5 percent anomalies of surface UVB as a function of latitude from ULAQ-CCM (c) (red) and GEOSCCM (blue) (2040-2049). UVB changes are shown for the two components that are explicitly online in the models (i.e., $\mathrm{O}_{3}$ and aerosols) and for their net. ULAQ-CCM results are taken from numerical experiment (c) in Table 1 in order to make a more meaningful comparison with GEOSCCM, as in Fig. 9.

(a) $\triangle \mathrm{OH}\left(10^{6} \mathrm{molec} \mathrm{cm}^{-3}\right)$ [G4(FBC)-RCP4.5]

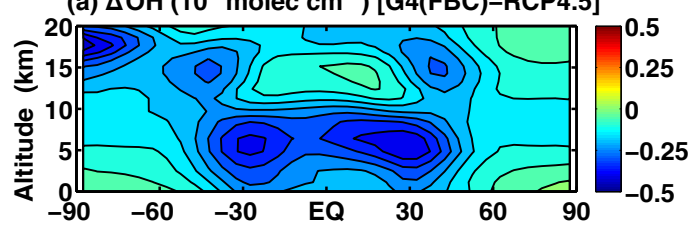

(b) $\Delta \mathrm{CH}_{4}$ (ppbv) [G4(FBC)-RCP4.5]

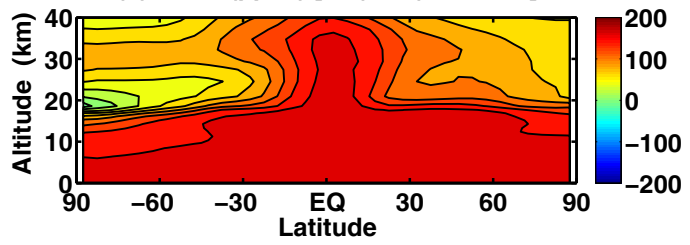

Figure 12. ULAQ-CCM calculated G4-RCP4.5 anomalies of (a) $\mathrm{OH}$ concentrations and (b) $\mathrm{CH}_{4}$ mixing ratios (time average 2040-2049) from experiment (b) in Table 1. Units are $10^{6}$ molec $\mathrm{cm}^{-3}$ for $\mathrm{OH}$ and ppbv for $\mathrm{CH}_{4}$. The contour line increment is $0.1 \times 10^{6}$ molec $\mathrm{cm}^{-3}$ for $\mathrm{OH}$ and $25 \mathrm{ppbv}$ for $\mathrm{CH}_{4}$.

burden and lifetime in ULAQ-CCM (b) for the year 2000. The major atmospheric sink of $\mathrm{CH}_{4}$ is the reaction with $\mathrm{OH}$ and this determines the $\mathrm{CH}_{4}$ lifetime, except for an additional smaller contribution from soil deposition and an additional stratospheric sink due to $\mathrm{CH}_{4}$ reactions with $\mathrm{O}\left({ }^{1} \mathrm{D}\right)$ and $\mathrm{Cl}$. The calculated $\mathrm{OH}$ abundance is then critical in the determination of a realistic global burden and lifetime of $\mathrm{CH}_{4}$. Tropospheric $\mathrm{OH}$ concentrations have been evaluated in Pitari et al. (2016a) using climatological values from Spivakovsky et al. (2000). In the same published work, a comparison of calculated tropospheric $\mathrm{CH}_{4}$ mixing ratios is made with observations from TES/Aura radiances.
Table 5. $\mathrm{CH}_{4}$ surface emissions, sinks, global mass burden and lifetime in the ULAQ-CCM for experiment (b) (year 2000).

\begin{tabular}{lr}
\hline Emissions $\left(\mathrm{Tg} \mathrm{yr}^{-1}\right)$ & ULAQ-CCM \\
Sinks $\left(\mathrm{Tg} \mathrm{yr}^{-1}\right)$ & $(\mathrm{FBC})$ \\
Burden $(\mathrm{Tg})$ & \\
Lifetime $(\mathrm{yr})$ & \\
\hline Natural sources & $230^{\mathrm{a}, \mathrm{b}}$ \\
(wetlands) & $160^{\mathrm{a}, \mathrm{b}}$ \\
(termites) & $20^{\mathrm{a}, \mathrm{b}}$ \\
(geological) & $50^{\mathrm{a}}$ \\
Anthropogenic sources & $340^{\mathrm{a}, \mathrm{c}}$ \\
(agriculture) & $125^{\mathrm{a}, \mathrm{c}}$ \\
(fossil fuel) & $100^{\mathrm{a}, \mathrm{c}}$ \\
(waste) & $79^{\mathrm{a}, \mathrm{c}}$ \\
(biomass burning) & $36^{\mathrm{a}, \mathrm{c}}$ \\
Total sources & $570^{\mathrm{a}, \mathrm{c}}$ \\
Soil deposition & $30^{\mathrm{a}}$ \\
Atmospheric loss $\left(\mathrm{OH} \mathrm{O}\left({ }^{1} \mathrm{D}\right) \mathrm{Cl}\right)$ & 540 \\
Total skins & 570 \\
Global mass burden & 4760 \\
Atmospheric lifetime & 8.8 \\
Global lifetime & 8.35 \\
\hline
\end{tabular}

${ }^{a}$ IPCC (2013). ${ }^{b}$ Wecht et al. (2014). ${ }^{c}$ Lamarque et al. (2010).

The ULAQ-CCM calculated time series of $\mathrm{CH}_{4}$ lifetime and surface mixing ratio is presented in Fig. 13a, for both reference RCP4.5 and perturbed G4 cases, using the FBC approach (experiment $\mathrm{b}$ in Table 1). A simple approach was used for the time evolution of $\mathrm{CH}_{4}$ emission fluxes: the geographical distribution was fixed at year 2000 values, but the net global value was linearly scaled to the ratio of RCP4.5 recommended surface mixing ratios in future years (dotted line in Fig. 13a) with the year 2000 recommended value (1754 ppbv). An in-depth study of future climate change effects on $\mathrm{CH}_{4}$ natural emissions or future changes on the geographical distribution of anthropogenic emissions is beyond the purposes of the present study. The lifetime change G4-RCP4.5 shown in Fig. 13a increases up to 1.7 years in 2070 during the time period of geoengineering implementation, then slowly decreases in the so-called termination period (2070-2090) down to 1.2 years in 2090. Similarly, the surface mixing ratio change increases up to $250 \mathrm{ppbv}$ in 2070 and then slowly decreases in the termination period down to $150 \mathrm{ppbv}$ in 2090 . These slow decreases are due to the long time needed for atmospheric $\mathrm{CH}_{4}$ to return to baseline RCP4.5 values. In addition, sea surface temperatures need a few decades to recover to RCP4.5 values (Fig. 6a, b), thus triggering a prolonged perturbation of the stratospheric circulation.

A summary of gas-phase radiative forcing (RF) components related to the $\mathrm{CH}_{4}$ perturbation is presented in Fig. 13b. Direct stratospheric aerosol RF obviously dominates in sulfate geoengineering $\left(\sim-1.2 \mathrm{~W} \mathrm{~m}^{-2}\right)$, as discussed in Visioni 
(a) $\mathrm{CH}_{4}$ atmospheric lifetime and surface mixing ratio

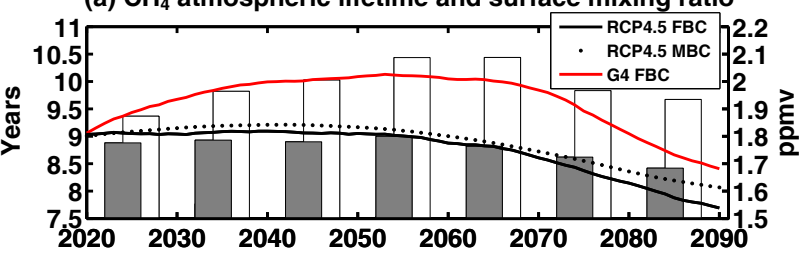

(b) $\mathrm{CH}_{4}$ direct and indirect RF [G4-RCP4.5]

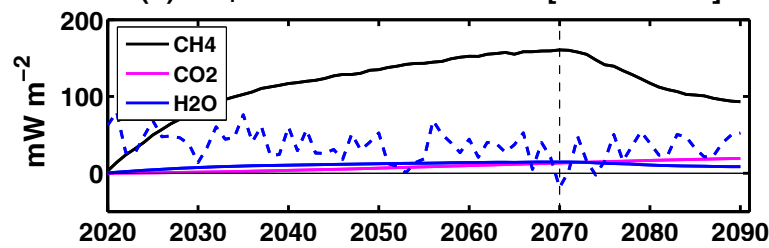

Figure 13. (a) Time series of $\mathrm{CH}_{4}$ global mean atmospheric lifetime (years, left scale, bars) calculated in the ULAQ-CCM FBC case (experiment $b$ of Table 1), with bars referring to decadal averages (gray for RCP4.5 and white for G4). Superimposed are globally averaged $\mathrm{CH}_{4}$ surface mixing ratios (ppmv, right scale) for the corresponding RCP4.5 and G4 simulations (black solid and red curves, respectively). The dotted curve shows globally averaged $\mathrm{CH}_{4}$ surface mixing ratios for the RCP4.5 MBC case (experiment a in Table 1), i.e., using prescribed fixed mixing ratios at the surface (Eyring et al., 2013). (b) Time series of G4-RCP4.5 radiative forcing of $\mathrm{CH}_{4}$ $\left(\mathrm{mW} \mathrm{m}^{-2}\right)$. Black, purple and blue curves show the direct and indirect effects (purple and blue curves are for $\mathrm{CO}_{2}$ and stratospheric $\mathrm{H}_{2} \mathrm{O}$ from $\mathrm{CH}_{4}$ oxidation, respectively). Dashed blue curve is for stratospheric $\mathrm{H}_{2} \mathrm{O}$ changes resulting from G4-RCP4.5 temperature anomalies at the tropopause tropical layer (TTL).

et al. (2017), using independent estimates available in the literature. Among gas species, $\mathrm{CH}_{4}$ produces the largest indirect $\mathrm{RF}\left(\sim+0.1 \mathrm{~W} \mathrm{~m}^{-2}\right)$, in addition to contributions from $\mathrm{O}_{3}$ (negative) and stratospheric $\mathrm{H}_{2} \mathrm{O}$ (positive), with the latter due to slight warming of the tropopause tropical layer (TTL) (see Pitari et al., 2014). Small indirect $\mathrm{CH}_{4}$ contributions come from increasing amounts of $\mathrm{CO}_{2}$ and $\mathrm{H}_{2} \mathrm{O}$ in the $\mathrm{CH}_{4}$ oxidation chain. This chemical increase of stratospheric $\mathrm{H}_{2} \mathrm{O}$, however, is normally smaller than the one driven by the geoengineering aerosol warming at the TTL cold point (as shown in Fig. 13b).

Table 6 summarizes our calculations for $\mathrm{OH}$-dependent species lifetimes under geoengineering conditions. The ULAQ-CCM calculated lifetimes under year 2000 conditions are fully comparable with the values in the SPARC (2013) report on lifetimes. G4-RCP4.5 anomalies averaged between 2030-2069 range between +1.33 years for $\mathrm{CH}_{4}$ and +0.5 years for $\mathrm{CH}_{3} \mathrm{CCl}_{3}$. The $\mathrm{FBC}$ approach was used for $\mathrm{CH}_{4}$ in order to properly evaluate its feedback on $\mathrm{HO}_{x}$ chemistry. The rightmost three columns in Table 6 show the different contributions to the lifetime changes, through G4 sensitivity experiments (sn1, sn2, sn3) explained in Table 2. The major contribution to the $\mathrm{CH}_{4}$ lifetime change (but also for HCFC-22 and $\mathrm{CH}_{3} \mathrm{CCl}_{3}$ ) comes from the presence of aerosols with their feedback on $\mathrm{NO}_{x}-\mathrm{HO}_{x}-\mathrm{O}_{3}$ photochemistry, as discussed before in Figs. 9, 10 and 11 (temperature and winds are kept unchanged with respect to RCP4.5 in the G4-sn1 sensitivity case, in the chemistry module and continuity equations of chemical tracers).

The effects of tropospheric cooling with decreased water vapor (due to solar radiation scattering by the stratospheric aerosols) and strengthening of the BDC with enhanced strattrop downward flux (due to heating rates by the stratospheric aerosols) tend to partially or completely cancel each other. The impact of tropospheric cooling on $\mathrm{OH}$-driven lifetimes is limited by the fact that the lowered $\mathrm{H}_{2} \mathrm{O}$ and $\mathrm{OH}$ production is partially counterbalanced by a less efficient reaction of $\mathrm{NO}+\mathrm{O}_{3} \rightarrow \mathrm{NO}_{2}+\mathrm{O}_{2}$ in a colder troposphere (see Fig. S8). This decreases $\mathrm{NO}_{2}$ and the $\mathrm{NO}_{x}$ sink to $\mathrm{HNO}_{3}$, which implies an $\mathrm{OH}$ increase, mostly in the upper troposphere. In addition, $\mathrm{OH}$ formation from $\mathrm{NO}+\mathrm{HO}_{2}$ reaction is enhanced if the $\mathrm{NO}$ loss on $\mathrm{O}_{3}$ is less efficient.

The strengthening of the Brewer-Dobson circulation affects essentially the upper tropospheric amount of $\mathrm{SO}_{4}, \mathrm{CH}_{4}$, $\mathrm{NO}_{y}$ and $\mathrm{O}_{3}$. This results in a negative anomaly for geoengineering $\mathrm{SO}_{4}$ and for $\mathrm{CH}_{4}$ (due to the enhanced lower stratospheric tropical confinement; see Figs. 8 and 5c) and a positive anomaly for $\mathrm{NO}_{y}$ and $\mathrm{O}_{3}$ (due to the enhanced strat-trop downward flux). The induced $\mathrm{OH}$ anomaly is negative from $\mathrm{CH}_{4}$ (a net $\mathrm{HO}_{x}$ source) and $\mathrm{O}_{3}$ (which is an $\mathrm{OH}$ sink in the upper troposphere). On the other hand, it is positive from $\mathrm{SO}_{4}$ and $\mathrm{NO}_{y}$ (due to the increasing $\mathrm{NO}_{x}$ amount, their negative or positive anomaly will produce). This positive $\mathrm{NO}_{x}$ anomaly induced in the upper troposphere by the enhanced stratospheric circulation mostly regulates the net positive $\mathrm{OH}$ change in the ULAQ-CCM with decreasing lifetimes (fifth column in Table 6).

\section{Conclusions}

In the present work, we have described how an injection of 5-8 Tg of $\mathrm{SO}_{2}$ per year would modify the large-scale transport and lifetime of $\mathrm{CH}_{4}$, using two climate-chemistry coupled models, ULAQ-CCM and GEOSCCM. Both models use prescribed SST coming from two atmosphere-ocean coupled models: CCSM-CAM4 for ULAQ-CCM and CESM for GEOSCCM. The model evaluation has shown that both models correctly simulate the vertical profiles for the chemical species under analysis $\left(\mathrm{N}_{2} \mathrm{O}\right.$ as a quasi-passive tracer and $\mathrm{CH}_{4}$ ), the mean age of air and the vertical velocity $w^{*}$. Furthermore, the latitudinal heat fluxes have been compared with ERA40 reanalysis in order to evaluate the skill of the models in correctly simulating the meridional transport.

We have shown that changes in the BDC due to lower stratospheric aerosol heating reduce the amount of $\mathrm{CH}_{4}$ in the extratropical UTLS. This is both because of the strengthening of the downward branches of the BDC which brings more stratospheric air (poorer in $\mathrm{CH}_{4}$ ) down in the upper 
Table 6. Atmospheric lifetimes (years) calculated in the ULAQ-CCM (experiment $b$ in Table 1), relative to three species that include an $\mathrm{OH}$ reaction sink (i.e., $\mathrm{CH}_{4}, \mathrm{HCFC}-22, \mathrm{CH}_{3} \mathrm{CCl}_{3}$ ). $\mathrm{CH}_{4}$ is predicted with the $\mathrm{FBC}$ approach; the other two species with specified surface mixing ratios (unchanged between G4 and RCP4.5). The first column shows year 2000 values (as an average over the 1996-2005 decade); the second column shows a model mean value from the SPARC (2013) report on lifetimes. Subsequent columns show the calculated lifetime anomalies due to sulfate geoengineering (average 2030-2069). Inside the brackets we highlight the physical and chemical effects driving the lifetime changes (see text).

\begin{tabular}{lrrrrrr}
\hline $1996-2005$ & $\begin{array}{r}\text { Model mean } \\
\text { (SPARC, 2013) }\end{array}$ & $\begin{array}{r}\text { 2030-2069 } \\
\text { G4-RCP4.5 } \\
\text { (all effects) }\end{array}$ & $\begin{array}{r}\text { 2030-2069 } \\
\text { G4-G4(sn2) } \\
\text { (temperature) }\end{array}$ & $\begin{array}{r}\text { 2030-2069 } \\
\text { G4-G4(sn3) } \\
\text { (transport) }\end{array}$ & $\begin{array}{r}\text { G4(sn1)-RCP4.5 } \\
\left(\mathrm{UV}+\mathrm{NO}_{2}+\mathrm{O}_{3}\right)\end{array}$ \\
\hline $\mathrm{CH}_{4}$ & 8.8 & $8.7 \pm 1.4$ & +1.33 & +0.31 & -0.28 & +1.30 \\
$\mathrm{HCFC}^{22}$ & 10.0 & $10.7 \pm 1.6$ & +0.83 & +0.42 & -0.29 & +0.70 \\
$\mathrm{CH}_{3} \mathrm{CCl}_{3}$ & 4.6 & $4.6 \pm 0.6$ & +0.50 & +0.10 & -0.10 & +0.50 \\
\hline
\end{tabular}

\section{Effects of sulfate geoengineering on $\mathrm{CH}_{4}$ [photochemistry + transport]}
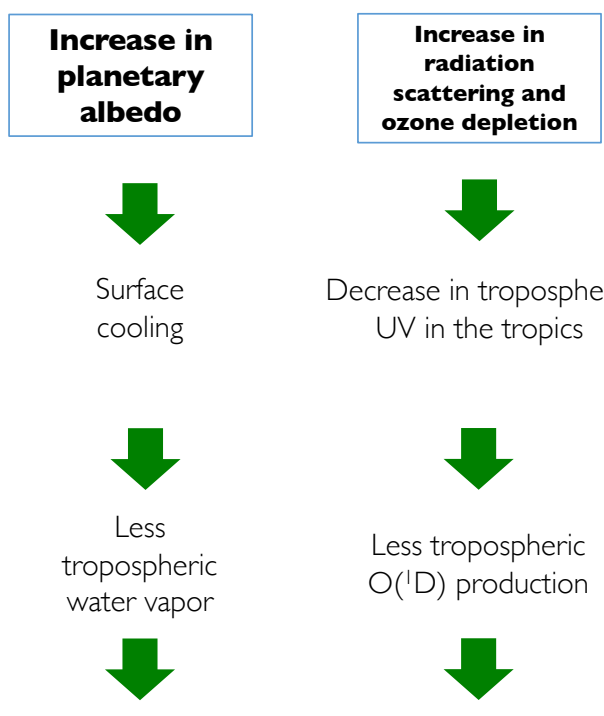

Decrease in tropospheric

UV in the tropics

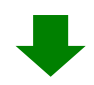

Less tropospheric

$\mathrm{O}(\mathrm{I} \mathrm{D})$ production

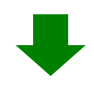

\section{Less $\mathrm{OH}$-> Longer $\mathrm{CH}_{4}$ lifetime}

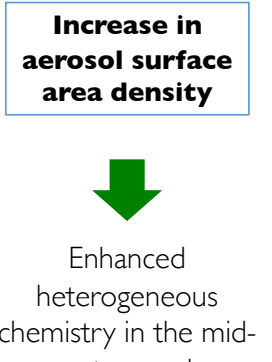

upper troposphere

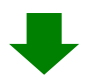

Less $\mathrm{NO}_{x}$ and

tropospheric $\mathrm{O}_{3}$

production

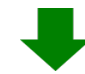

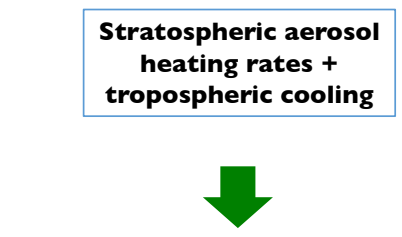

Enhanced STRAT-TROP downwelling

in the extratropics \& less

horizontal eddy mixing out of the

tropical pipe

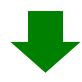

\section{Impact on UTLS HO $x$ chemistry and $\mathrm{CH}_{4}$ lifetime}

Figure 14. Visual representation of the photochemical and transport effects of sulfate geoengineering on $\mathrm{CH}_{4}$, as studied in this paper. Effects connected to perturbed $\mathrm{CH}_{4}$ emissions due to surface cooling are not shown because they were not explicitly considered in this study. These effects are essentially a decrease in wetland areas connected to reductions in rainfall and halting of permafrost thawing.

troposphere and because of a greater isolation of the tropical pipe that reduces the amount of horizontal mixing. However, in order to properly assess the magnitude of the transport perturbation (whether it is horizontal mixing or vertical fluxes), the addition of the feedback of the ocean has proven crucial. Cooler oceans allow for a further atmospheric stabilization of the atmosphere, and the cooling of the subArctic regions produces important hemispheric asymmetries that are not found in fixed SSTs simulations. This points to a important limitation of pure CCM studies, with prescribed time-dependent SSTs consistent with a given RCP scenario. The large-scale transport effects of sulfate geoengineering on trace species can only be captured on all their nonlinear aspects using coupled atmosphere-ocean global circulation model (AOGCM) simulations, which may quantify the SGinduced changes on SSTs. These can, in turn, be used as input for the aerosol-chemistry-radiation-dynamics fully interactive CCM experiments.

Furthermore, we have shown that the changes in $\mathrm{CH}_{4}$ lifetime and concentration take place because of a reduction of atmospheric $\mathrm{OH}$, mostly due to three overlapping factors: (1) reduction in tropospheric water vapor caused by the surface cooling; (2) decrease in $\mathrm{O}\left({ }^{1} \mathrm{D}\right)$ caused by a decrease in tropical tropospheric UV (because part of the incoming so- 
lar radiation is scattered by the stratospheric aerosols, which also deplete stratospheric ozone); (3) decrease in $\mathrm{NO}_{x}$ production caused by the enhancing of heterogeneous chemistry (see visual summary in Fig. 14). Changes in stratospheric large-scale transport and strat-trop exchange may also contribute to perturb the tropospheric amount of $\mathrm{OH}$, with a net effect whose sign results from simultaneous changes of $\mathrm{CH}_{4}$, $\mathrm{NO}_{y}, \mathrm{O}_{3}$ and $\mathrm{SO}_{4}$. All of these effects may cause a $\mathrm{CH}_{4}$ lifetime increase of more than 1 year in the central decades of the experiment, leading, in turn, to an increase in methane mixing ratio of over $200 \mathrm{ppbv}$.

Overall, these changes produce a positive radiative forcing of more than $+0.1 \mathrm{~W} \mathrm{~m}^{-2}$ in our radiative transfer model calculations, a result that it is still 1 order of magnitude smaller than the direct negative radiative forcing of the aerosols, which has been estimated to be $-1.2 \pm 0.5 \mathrm{~W} \mathrm{~m}^{-2}$ for a $5 \mathrm{Tg} \mathrm{SO}_{2} \mathrm{yr}^{-1}$ injection, considering simulations from a vast array of models (Visioni et al., 2017). In addition, gas species concentration changes (especially ozone) would also affect air quality and surface UV concentrations, which might have implications on human health, as already noted in Xia et al. (2017) and Nowack et al. (2016). As discussed in the present study, as well as in Nowack et al. (2016), Tilmes et al. (2012) and Pitari et al. (2014), the stratospheric ozone depletion induced by geoengineering solar radiation management techniques directly impacts the tropospheric UV budget. The health impact of a surface UV enhancement (located only at mid-to-high latitudes in the case of sulfate geoengineering) may be partly counterbalanced by the decreased tropospheric $\mathrm{OH}$ concentration and $\mathrm{O}_{3}$ production.

Our analysis is limited to an atmospheric perturbation produced by sulfate geoengineering on photochemistry and large-scale transport; other important changes that would happen under this hypothetic scenario are the ones in natural surface emissions of $\mathrm{CH}_{4}$ that would occur following changes in surface temperatures. Natural emissions would be reduced under sulfate geoengineering for three main reasons: (1) a reduction in surface temperatures that would, in turn, be connected with a highly probable reduction in rainfall, compared with the predicted increase under most future warming scenarios (Trenberth, 1998; Pandey et al., 2017); this would reduce the amount of $\mathrm{CH}_{4}$ produced by wetland areas, thus affecting the atmospheric methane concentration; (2) the increased surface deposition of sulfate under SG conditions would itself produce changes in emissions from wetlands (Gauci et al., 2008); (3) SG could help avert one of the possible risks of global warming, i.e., the emission of methane from permafrost thawing (Kohnert et al., 2017). It remains to be investigated how much these effects, together, could offset the photochemical $\mathrm{CH}_{4}$ increase resulting from our study.

Data availability. Data from model simulations are available from the corresponding author.

\section{The Supplement related to this article is available online at https://doi.org/10.5194/acp-17-11209-2017- supplement.}

Competing interests. The authors declare that they have no conflict of interest.

Special issue statement. This article is part of the special issue "The Geoengineering Model Intercomparison Project (GeoMIP): Simulations of solar radiation reduction methods (ACP/GMD interjournal SI)". It does not belong to a conference.

Acknowledgements. Figures 1, S1, S2 and S3 were produced with the ESMValTool (Eyring et al., 2016). GEOSCCM simulations performed by Valentina Aquila were supported by the NASA High-End Computing (HEC) Program through the NASA Center for Climate Simulations (NCCS) at Goddard Space Flight Center. Irene Cionni acknowledges funding received from the European Union's Horizon 2020 research and innovation programme under grant agreement no. 641816 (CRESCENDO). The authors would like to thank Renaud de Richter and Peer Johannes Nowack for their insightful comments regarding the conclusions of this study.

Edited by: Ben Kravitz

Reviewed by: two anonymous referees

\section{References}

Aquila, V., Oman, L. D., Stolarski, R., Douglass, A. R., and Newman, P. A.: The Response of Ozone and Nitrogen Dioxide to the Eruption of Mt. Pinatubo at Southern and Northern Midlatitudes, J. Atmos. Sci., 70, 894-900, https://doi.org/10.1175/JAS-D-120143.1, 2013.

Aquila, V., Garfinkel, C., Newman, P., Oman, L., and Waugh, D.: Modifications of the quasi-biennial oscillation by a geoengineering perturbation of the stratospheric aerosol layer, Geophys. Res. Lett., 41, 1738-1744, 2014.

Bais, A. F., Tourpali, K., Kazantzidis, A., Akiyoshi, H., Bekki, S., Braesicke, P., Chipperfield, M. P., Dameris, M., Eyring, V., Garny, H., Iachetti, D., Jöckel, P., Kubin, A., Langematz, U., Mancini, E., Michou, M., Morgenstern, O., Nakamura, T., Newman, P. A., Pitari, G., Plummer, D. A., Rozanov, E., Shepherd, T. G., Shibata, K., Tian, W., and Yamashita, Y.: Projections of UV radiation changes in the 21st century: impact of ozone recovery and cloud effects, Atmos. Chem. Phys., 11, 7533-7545, https://doi.org/10.5194/acp-11-7533-2011, 2011.

Bândă, N., Krol, M., van Weele, M., van Noije, T., and Röckmann, T.: Analysis of global methane changes after the 1991 Pinatubo volcanic eruption, Atmos. Chem. Phys., 13, 22672281, https://doi.org/10.5194/acp-13-2267-2013, 2013.

Banda, N., Krol, M., van Noije, T., van Weele, M., Williams, J. E., Sager, P. L., Niemeier, U., Thomason, L., and Rockmann, T.: The effect of stratospheric sulfur from Mount Pinatubo on tropospheric oxidizing capacity and 
methane, J. Geophys. Res.-Atmos., 120, 1202-1220, https://doi.org/10.1002/2014JD022137, 2015.

Bluth, G. J. S., Doiron, S. D., Schnetzler, C. C., Krueger, A. J., and Walter, L. S.: Global tracking of the $\mathrm{SO}_{2}$ clouds from the June, 1991 Mount Pinatubo eruptions, Geophys. Res. Lett., 19, 151154, https://doi.org/10.1029/91GL02792, 1992.

Canty, T., Mascioli, N. R., Smarte, M. D., and Salawitch, R. J.: An empirical model of global climate - Part 1: A critical evaluation of volcanic cooling, Atmos. Chem. Phys., 13, 3997-4031, https://doi.org/10.5194/acp-13-3997-2013, 2013.

Crutzen, P. J.: Albedo Enhancement by Stratospheric Sulfur Injections: A Contribution to Resolve a Policy Dilemma?, Climatic Change, 77, 211-220, https://doi.org/10.1007/s10584-006-9101y, 2006.

Dlugokencky, E. J., Steele, L. P., Lang, P. M., and Masarie, K. A.: The growth rate and distribution of atmospheric methane, J. Geophys. Res.-Atmos., 99, 17021-17043, https://doi.org/10.1029/94JD01245, 1994.

Eyring, V., Butchart, N., Waugh, D. W., Akiyoshi, H., Austin, J., Bekki, S., Bodeker, G. E., Boville, B. A., Bruhl, C., Chipperfield, M. P., Cordero, E., Dameris, M., Deushi, M., Fioletov, V. E., Frith, S. M., Garcia, R. R., Gettelman, A., Giorgetta, M. A., Grewe, V., Jourdain, L., Kinnison, D. E., Mancini, E., Manzini, E., Marchand, M., Marsh, D. R., Nagashima, T., Newman, P. A., Nielsen, J. E., Pawson, S., Pitari, G., Plummer, D. A., Rozanov, E., Schraner, M., Shepherd, T. G., Shibata, K., Stolarski, R. S., Struthers, H., Tian, W., and Yoshiki, M.: Assessment of temperature, trace species, and ozone in chemistry-climate model simulations of the recent past, J. Geophys. Res.-Atmos., 111, D22308, https://doi.org/10.1029/2006JD007327, d22308, 2006.

Eyring, V., Lamarque, J.-F., Hess, P. et al.: Overview of IGAC/SPARC Chemistry-Climate Model Initiative (CCMI) Community Simulations in Support of Upcoming Ozone and Climate Assessment, SPARC Newsletter, 40, 48-66, 2013.

Eyring, V., Righi, M., Lauer, A., Evaldsson, M., Wenzel, S., Jones, C., Anav, A., Andrews, O., Cionni, I., Davin, E. L., Deser, C., Ehbrecht, C., Friedlingstein, P., Gleckler, P., Gottschaldt, K.D., Hagemann, S., Juckes, M., Kindermann, S., Krasting, J., Kunert, D., Levine, R., Loew, A., Mäkelä, J., Martin, G., Mason, E., Phillips, A. S., Read, S., Rio, C., Roehrig, R., Senftleben, D., Sterl, A., van Ulft, L. H., Walton, J., Wang, S., and Williams, K. D.: ESMValTool (v1.0) - a community diagnostic and performance metrics tool for routine evaluation of Earth system models in CMIP, Geosci. Model Dev., 9, 1747-1802, https://doi.org/10.5194/gmd-9-1747-2016, 2016.

Gauci, V., Dise, N. B., Howell, G., and Jenkins, M. E.: Suppression of rice methane emission by sulfate deposition in simulated acid rain, J. Geophys. Res.-Biogeo., 113, g00A07, https://doi.org/10.1029/2007JG000501, 2008.

Grooß, J.-U. and Russell III, J. M.: Technical note: A stratospheric climatology for $\mathrm{O}_{3}, \mathrm{H}_{2} \mathrm{O}, \mathrm{CH}_{4}, \mathrm{NO}_{x}, \mathrm{HCl}$ and $\mathrm{HF}$ derived from HALOE measurements, Atmos. Chem. Phys., 5, 2797-2807, https://doi.org/10.5194/acp-5-2797-2005, 2005.

Hegglin, M. I., Gettelman, A., Hoor, P., Krichevsky, R., Manney, G. L., Pan, L. L., Son, S.-W., Stiller, G., Tilmes, S., Walker, K. A., Eyring, V., Shepherd, T. G., Waugh, D., Akiyoshi, H., Anel, J. A., Austin, J., Baumgaertner, A., Bekki, S., Braesicke, P., Bruhl, C., Butchart, N., Chipperfield, M. P., Dameris, M., Dhomse, S., Frith, S., Garny, H., Hardiman, S. C., Jockel, P.,
Kinnison, D. E., Lamarque, J. F., Mancini, E., Michou, M., Morgenstern, O., Nakamura, T., Olivie, D., Pawson, S., Pitari, G., Plummer, D. A., Pyle, J. A., Rozanov, E., Scinocca, J. F., Shibata, K., Smale, D., Teyssedre, H., Tian, W., and Yamashita, Y.: Multimodel assessment of the upper troposphere and lower stratosphere: Extra-tropics, J. Geophys. Res.-Atmos., 115, D00M09, https://doi.org/10.1029/2010JD013884, 2010.

IPCC: Climate Change 2013: The Physical Science Basis. Contribution of Working Group I to the Fifth Assessment Report of the Intergovernmental Panel on Climate Change, Cambridge Univ. Press, Cambridge, 2013.

Kohnert, K., Serafimovich, A., Metzger, S., Hartmann, J., and Sachs, T.: Strong geologic methane emissions from discontinuous terrestrial permafrost in the Mackenzie Delta, Canada, Scientific Reports, 7, 5828, https://doi.org/10.1038/s41598-01705783-2, 2017.

Kravitz, B., Robock, A., Boucher, O., Schmidt, H., Taylor, K. E., Stenchikov, G., and Schulz, M.: The Geoengineering Model Intercomparison Project (GeoMIP), Atmos. Sci. Lett., 12, 162167, https://doi.org/10.1002/asl.316, 2011.

Kravitz, B., Robock, A., and Haywood, J. M.: Progress in climate model simulations of geoengineering, EOS T. Am. Geophys. Un., 93, 340-340, https://doi.org/10.1029/2012EO350009, 2012.

Labitzke, K. and McCormick, M. P.: Stratospheric temperature increases due to Pinatubo aerosols, Geophys. Res. Lett., 19, $207-$ 210, https://doi.org/10.1029/91GL02940, 1992.

Lamarque, J.-F., Bond, T. C., Eyring, V., Granier, C., Heil, A., Klimont, Z., Lee, D., Liousse, C., Mieville, A., Owen, B., Schultz, M. G., Shindell, D., Smith, S. J., Stehfest, E., Van Aardenne, J., Cooper, O. R., Kainuma, M., Mahowald, N., McConnell, J. R., Naik, V., Riahi, K., and van Vuuren, D. P.: Historical (1850-2000) gridded anthropogenic and biomass burning emissions of reactive gases and aerosols: methodology and application, Atmos. Chem. Phys., 10, 7017-7039, https://doi.org/10.5194/acp-10-7017-2010, 2010.

Lambert, A., Grainger, R. G., Remedios, J. J., Rodgers, C. D., Corney, M., and Taylor, F. W.: Measurements of the evolution of the Mt. Pinatubo aerosol cloud by ISAMS, Geophys. Res. Lett., 20, 1287-1290, 1993.

Long, C. S. and Stowe, L. L.: using the NOAA/AVHRR to study stratospheric aerosol optical thicknesses following the Mt. Pinatubo Eruption, Geophys. Res. Lett., 21, 2215-2218, https://doi.org/10.1029/94GL01322, 1994.

McCormick, M. P. and Veiga, R. E.: SAGE II measurements of early Pinatubo aerosols, Geophys. Res. Lett., 19, 155-158, https://doi.org/10.1029/91GL02790, 1992.

Morgenstern, O., Giorgetta, M. A., Shibata, K., Eyring, V., Waugh, D. W., Shepherd, T. G., Akiyoshi, H., Austin, J., Baumgaertner, A. J. G., Bekki, S., Braesicke, P., Bruhl, C., Chipperfield, M. P., Cugnet, D., Dameris, M., Dhomse, S., Frith, S. M., Garny, H., Gettelman, A., Hardiman, S. C., Hegglin, M. I., Jockel, P., Kinnison, D. E., Lamarque, J.-F., Mancini, E., Manzini, E., Marchand, M., Michou, M., Nakamura, T., Nielsen, J. E., Olivie, D., Pitari, G., Plummer, D. A., Rozanov, E., Scinocca, J. F., Smale, D., Teyssedre, H., Toohey, M., Tian, W., and Yamashita, Y.: Review of the formulation of presentgeneration stratospheric chemistry-climate models and associated external forcings, J. Geophys. Res.-Atmos., 115, d00M02, https://doi.org/10.1029/2009JD013728, 2010. 
Morgenstern, O., Hegglin, M. I., Rozanov, E., O’Connor, F. M., Abraham, N. L., Akiyoshi, H., Archibald, A. T., Bekki, S., Butchart, N., Chipperfield, M. P., Deushi, M., Dhomse, S. S., Garcia, R. R., Hardiman, S. C., Horowitz, L. W., Jöckel, P., Josse, B., Kinnison, D., Lin, M., Mancini, E., Manyin, M. E., Marchand, M., Marécal, V., Michou, M., Oman, L. D., Pitari, G., Plummer, D. A., Revell, L. E., Saint-Martin, D., Schofield, R., Stenke, A., Stone, K., Sudo, K., Tanaka, T. Y., Tilmes, S., Yamashita, Y., Yoshida, K., and Zeng, G.: Review of the global models used within phase 1 of the Chemistry-Climate Model Initiative (CCMI), Geosci. Model Dev., 10, 639-671, https://doi.org/10.5194/gmd-10-639-2017, 2017.

Myhre, G., Shine, K., Radel, G., Gauss, M., Isaksen, I., Tang, Q., Prather, M., Williams, J., van Velthoven, P., Dessens, O., Koffi, B., Szopa, S., Hoor, P., Grewe, V., Borken-Kleefeld, J., Berntsen, T., and Fuglestvedt, J.: Radiative forcing due to changes in ozone and methane caused by the transport sector, Atmos. Environ., 45, 387-394, https://doi.org/10.1016/j.atmosenv.2010.10.001, 2011.

Neu, J. L. and Plumb, R. A.: Age of air in a "leaky pipe" model of stratospheric transport, J. Geophys. Res.-Atmos., 104, 1924319255, https://doi.org/10.1029/1999JD900251, 1999.

Nowack, P. J., Abraham, N. L., Braesicke, P., and Pyle, J. A.: Stratospheric ozone changes under solar geoengineering: implications for UV exposure and air quality, Atmos. Chem. Phys., 16, 41914203, https://doi.org/10.5194/acp-16-4191-2016, 2016.

Pandey, S., Houweling, S., Krol, M., Aben, I., Monteil, G., NechitaBanda, N., Dlugokencky, E. J., Detmers, R., Hasekamp, O., Xu, X., Riley, W. J., Poulter, B., Zhang, Z., McDonald, K. C., White, J. W. C., Bousquet, P., and Röckmann, T.: Enhanced methane emissions from tropical wetlands during the $2011 \mathrm{La}$ Niña, Scientific Reports, 7, 45759, https://doi.org/10.1038/srep45759, 2017.

Pitari, G., Aquila, V., Kravitz, B., Robock, A., Watanabe, S., Cionni, I., Luca, N. D., Genova, G. D., Mancini, E., and Tilmes, S.: Stratospheric ozone response to sulfate geoengineering: Results from the Geoengineering Model Intercomparison Project (GeoMIP), J. Geophys. Res.-Atmos., 119, 2629-2653, https://doi.org/10.1002/2013JD020566, 2014.

Pitari, G., Cionni, I., Di Genova, G., Sovde, O. A., and Lim, L.: Radiative forcing from aircraft emissions of $\mathrm{NO}_{x}$ : model calculations with $\mathrm{CH}_{4}$ surface flux boundary condition, Meteorol. Z., https://doi.org/10.1127/metz/2016/0776, 2016a.

Pitari, G., Cionni, I., Di Genova, G., Visioni, D., Gandolfi, I., and Mancini, E.: Impact of Stratospheric Volcanic Aerosols on Ageof-Air and Transport of Long-Lived Species, Atmosphere, 7, 149, https://doi.org/10.3390/atmos7110149, $2016 \mathrm{~b}$.

Pitari, G., Di Genova, G., Mancini, E., Visioni, D., Gandolfi, I., and Cionni, I.: Stratospheric Aerosols from Major Volcanic Eruptions: A Composition-Climate Model Study of the Aerosol Cloud Dispersal and e-folding Time, Atmosphere, 7, 75, https://doi.org/10.3390/atmos7060075, 2016c.

Randles, C. A., Kinne, S., Myhre, G., Schulz, M., Stier, P., Fischer, J., Doppler, L., Highwood, E., Ryder, C., Harris, B., Huttunen, J., Ma, Y., Pinker, R. T., Mayer, B., Neubauer, D., Hitzenberger, R., Oreopoulos, L., Lee, D., Pitari, G., Di Genova, G., Quaas, J., Rose, F. G., Kato, S., Rumbold, S. T., Vardavas, I., Hatzianastassiou, N., Matsoukas, C., Yu, H., Zhang, F., Zhang, H., and $\mathrm{Lu}, \mathrm{P}$.: Intercomparison of shortwave radiative transfer schemes in global aerosol modeling: results from the AeroCom Radia- tive Transfer Experiment, Atmos. Chem. Phys., 13, 2347-2379, https://doi.org/10.5194/acp-13-2347-2013, 2013.

Robock, A., Kravitz, B., and Boucher, O.: Standardizing experiments in geoengineering, EOS T. Am. Geophys. Un., 92, $197-$ 197, https://doi.org/10.1029/2011EO230008, 2011.

Russell, J. M., Gordley, L. L., Park, J. H., Drayson, S. R., Hesketh, W. D., Cicerone, R. J., Tuck, A. F., Frederick, J. E., Harries, J. E., and Crutzen, P. J.: The Halogen Occultation Experiment, J. Geophys. Res.-Atmos., 98, 10777-10797, https://doi.org/10.1029/93JD00799, 1993.

Sankey, D. and Shepherd, T. G.: Correlations of long-lived chemical species in a middle atmosphere general circulation model, J. Geophys. Res.-Atmos., 108, 4494, https://doi.org/10.1029/2002JD002799, 2003.

Schauffler, S. M. and Daniel, J. S.: On the effects of stratospheric circulation changes on trace gas trends, J. Geophys. Res.-Atmos. 99, 25747-25754, https://doi.org/10.1029/94JD02223, 1994.

Soden, B. J., Wetherald, R. T., Stenchikov, G. L., and Robock, A.: Global Cooling After the Eruption of Mount Pinatubo: A Test of Climate Feedback by Water Vapor, Science, 296, 727-730, https://doi.org/10.1126/science.296.5568.727, 2002.

SPARC: Chapter 5: Model Estimates of Lifetimes in SPARC Report on Lifetimes of Stratospheric Ozone-Depleting Substances, Their Replacements, and Related Species, edited by: Chipperfield, M., Liang, Q., Abraham, L., Bekki, S., Braesicke, P., Dhomse, S., Di Genova, G., Fleming, E. L., Hardiman, S., Iachetti, D., Jackman, C. H., Kinnison, D. E., Marchand, M., Pitari, G., Rozanov, E., Stenke, A., and Tummon, F., Tech. rep., SPARC, available at: http://www.sparc-climate.org/publications/ sparc-reports/ (last acces: 20 September 2017), 2013.

SPARC-CCMVal: SPARC Report on the evaluation of chemistryclimate models, SPARC Report, WCRP-132, WMO/TD-No, 2010.

Spivakovsky, C. M., Logan, J. A., Montzka, S. A., Balkanski, Y. J., Foreman-Fowler, M., Jones, D. B. A., Horowitz, L. W., Fusco, A. C., Brenninkmeijer, C. A. M., Prather, M. J., Wofsy, S. C., and McElroy, M. B.: Three-dimensional climatological distribution of tropospheric $\mathrm{OH}$ : Update and evaluation, J. Geophys. Res.-Atmos., 105, 8931-8980, https://doi.org/10.1029/1999JD901006, 2000.

Strahan, S. E., Douglass, A. R., Stolarski, R. S., Akiyoshi, H., Bekki, S., Braesicke, P., Butchart, N., Chipperfield, M. P., Cugnet, D., Dhomse, S., Frith, S. M., Gettelman, A., Hardiman, S. C., Kinnison, D. E., Lamarque, J.-F., Mancini, E., Marchand, M., Michou, M., Morgenstern, O., Nakamura, T., Olivie, D., Pawson, S., Pitari, G., Plummer, D. A., Pyle, J. A., Scinocca, J. F., Shepherd, T. G., Shibata, K., Smale, D., Teyssedre, H., Tian, W., and Yamashita, Y.: Using transport diagnostics to understand chemistry climate model ozone simulations, J. Geophys. Res.Atmos., 116, d17302, https://doi.org/10.1029/2010JD015360, 2011.

Taylor, K. E., Stouffer, R. J., and Meehl, G. A.: An overview of CMIP5 and the experiment design, B. Am. Meteorol. Soc., 93, 485-498, https://doi.org/10.1175/BAMS-D-11-00094.1, 2012.

Tilmes, S., Garcia, R. R., Kinnison, D. E., Gettelman, A., and Rasch, P. J.: Impact of geoengineered aerosols on the troposphere and stratosphere, J. Geophys. Res.-Atmos., 114, d12305, https://doi.org/10.1029/2008JD011420, 2009. 
Tilmes, S., Kinnison, D. E., Garcia, R. R., Salawitch, R., Canty, T., Lee-Taylor, J., Madronich, S., and Chance, K.: Impact of very short-lived halogens on stratospheric ozone abundance and UV radiation in a geo-engineered atmosphere, Atmos. Chem. Phys., 12, 10945-10955, https://doi.org/10.5194/acp-12-109452012, 2012.

Tilmes, S., Lamarque, J.-F., Emmons, L. K., Kinnison, D. E., Marsh, D., Garcia, R. R., Smith, A. K., Neely, R. R., Conley, A., Vitt, F., Val Martin, M., Tanimoto, H., Simpson, I., Blake, D. R., and Blake, N.: Representation of the Community Earth System Model (CESM1) CAM4-chem within the ChemistryClimate Model Initiative (CCMI), Geosci. Model Dev., 9, 18531890, https://doi.org/10.5194/gmd-9-1853-2016, 2016.

Trenberth, K. E.: Atmospheric Moisture Residence Times and Cycling: Implications for Rainfall Rates and Climate Change, Climatic Change, 39, 667-694, https://doi.org/10.1023/A:1005319109110, 1998.

Trepte, C. R. and Hitchman, M. H.: Tropical stratospheric circulation deduced from satellite aerosol data, Nature, 355, 626-628, https://doi.org/10.1038/355626a0, 1992.

Urban, J., Pommier, M., Murtagh, D. P., Santee, M. L., and Orsolini, Y. J.: Nitric acid in the stratosphere based on Odin observations from 2001 to 2009 - Part 1: A global climatology, Atmos. Chem. Phys., 9, 7031-7044, https://doi.org/10.5194/acp-9-70312009, 2009.
Visioni, D., Pitari, G., and Aquila, V.: Sulfate geoengineering: a review of the factors controlling the needed injection of sulfur dioxide, Atmos. Chem. Phys., 17, 3879-3889, https://doi.org/10.5194/acp-17-3879-2017, 2017.

Wecht, K. J., Jacob, D. J., Frankenberg, C., Jiang, Z., and Blake, D. R.: Mapping of North American methane emissions with high spatial resolution by inversion of SCIAMACHY satellite data, J. Geophys. Res.-Atmos., 119, 77417756, https://doi.org/10.1002/2014JD021551, 2014.

Worden, J., Kulawik, S., Frankenberg, C., Payne, V., Bowman, K., Cady-Peirara, K., Wecht, K., Lee, J.-E., and Noone, D.: Profiles of $\mathrm{CH}_{4}, \mathrm{HDO}, \mathrm{H}_{2} \mathrm{O}$, and $\mathrm{N}_{2} \mathrm{O}$ with improved lower tropospheric vertical resolution from Aura TES radiances, Atmos. Meas. Tech., 5, 397-411, https://doi.org/10.5194/amt-5397-2012, 2012.

Xia, L., Nowack, P. J., Tilmes, S., and Robock, A.: Impacts of Stratospheric Sulfate Geoengineering on Tropospheric Ozone, Atmos. Chem. Phys. Discuss., https://doi.org/10.5194/acp-2017434, in review, 2017. 